\title{
Gender, Class and Competition
}

\section{Safeguarding Patriarchal Metropolitan Privileges IN BOTANY}

Mary Barber was excluded from the general historiography of botany on account of her gender. Colonial botanists already struggled for acknowledgement from the scientists guarding the metropolitan herbaria, botanical gardens, chairs of botany and collections. In 1886, the British colonial botanist Peter MacOwan (1830-1909) published a historical overview of botanists' achievements in South Africa. In it, he gave vent to his frustration by claiming that 'at best one can only expect to be tolerated. Not applauded, by others than the initiated few'. However, he himself only included men's achievements in the field of botany, illustrating how exclusionary the circle of botanists was at the Cape itself. ${ }^{1}$

Barber had long hoped to make a living as a botanical illustrator. In October 1848 and March 1849, William Guybon Atherstone wrote to William Jackson Hooker, the director of the Royal Botanic Gardens Kew, to enquire whether he could pay Barber for her illustrations or employ her as an illustrator for Curtis's Botanical Magazine. ${ }^{2}$ This monthly magazine was published in London with six coloured plates in each edition representing 'correct' and 'beautiful portraits' of exotic plants new to British gardens. ${ }^{3}$ Yet Hooker, the magazine's editor, did not have the financial means to employ or pay colonial collectors or illustrators. After the financial losses which she and her family had suffered during the

(C) The Author(s) 2019

T. Hammel, Shaping Natural History and Settler Society, Cambridge Imperial and Post-Colonial Studies Series, https://doi.org/10.1007/978-3-030-22639-8_4 
Seventh Cape-Xhosa War, Barber and Atherstone might have hoped that she could earn a living as an illustrator as Atherstone detested seeing his relatives in poverty. As a matter of fact, there were painters in Albany who successfully worked as illustrators-one of them was Frederick Timpson I'Ons, who arrived at the start of the Sixth Cape-Xhosa War (1834-1835). ${ }^{4}$ Barber's desire to be a botanical illustrator is striking and significant, a clear glimpse of her own vision of herself which is not always easy to detect in other women academics' careers.

The lack of illustrations in Harvey's Genera of South African Plants (1838) - the first book on Cape flora published at the Cape which Barber most likely borrowed from Grahamstown surgeon Dr. John Atherstone, who had a considerable private library ${ }^{5}$-motivated Barber to introduce herself to Harvey by offering her services as an illustrator for his subsequent volume. Harvey's brother Joseph had been made the colonial treasurer in 1835 and William had accompanied him to Cape Town where he botanised in this new environment. When Joseph's health failed and he died on the passage home in 1836, William became his successor as the treasurer and resided at Bishop's Court. Using this as a base, he would wake up before dawn to collect in the mountains or on the seashore, before working on his collected specimens at night. In March 1837, he reported having been on so many excursions that he feared earning 'the sobriquet of Her Majesty's pleasurer general'. ${ }^{6}$ Depression may have been the reason why he left the Cape in $1842 .^{7}$ In 1844 , he was appointed the keeper of the herbarium at Trinity College Dublin where, twelve years later, he became the professor of botany.

Shortly after reading Genera of South African Plants, Barber began sending Harvey specimens and information anonymously. In the beginning, she had acquaintances from Albany, such as Atherstone and Peter MacOwan, to forward her letters to Harvey. ${ }^{8}$ In reply, he is said to have addressed Barber as M. Bowker Esq. during the first year of their correspondence before she would introduce herself properly. ${ }^{9}$ This was common practice at the time. If Darwin received letters with only surnames, he naturally replied 'Dear Sir' ${ }^{10}$ It is likely that she did not reveal her gender out of fear that he would perceive her as a 'lady-friend', Harvey's, in Barber's eyes disparaging, term for the target audience of his Genera of South African Plants. ${ }^{11}$ Instead, she was determined to be recognised as a botanist in her own right.

She may also have been dependent on men forwarding her letters due to the financial difficulties the family experienced after the Seventh Cape-Xhosa 
War. Presumably unable to afford postage, she had to ensure she could convince Harvey to cover for the costs successfully so. Harvey accumulated 22,800 specimens in total, and the Barber/Bowker collection was one of seven which contained more than $1000 .^{12}$

Barber also convinced Harvey of the importance of illustrations, particularly for addressing a broad readership, and Harvey would later produce an average of one lithographed plate a week. ${ }^{13}$ Illustrations thus became Harvey and Barber's shared interest and allowed them to exchange knowledge about plants more efficiently than through their letters. Indeed, they despised writing long letters and welcomed the possibility of circulating knowledge in a much more condensed form.

Barber, however, was not satisfied with merely providing the basis for Harvey's illustrations. Harvey copied from her and her specimens when creating the 100 sketches for Thesaurus Capensis, or Illustrations of the South African Flora that accompanied Flora Capensis (1860-1865). While Harvey never published any of her illustrations, Barber was zealously determined that a broader public should be able to see them. In 1863, she wrote to Trimen offering her services as an illustrator, highlighting that illustrating was 'no easy task and no little trouble'. ${ }^{14}$

In a similar fashion, Katharine Saunders in Tongaat, Natal, simultaneously claimed that illustrating was difficult for a woman at the time, as time was scarce when she had many children and a large household to take care of. Saunders had to contend herself with painting at night under bad candle light while using unsuitable equipment, all of which she frequently noted on the back and side of her watercolours, a valuable source for understanding the circumstances under which women at the time contributed to science. ${ }^{15}$

Towards the end of Harvey's life, a period during which he suffered from grave illness, Barber was afraid that he would not name a Brachystelma, which she claimed to have discovered, after her. Foreknowingly, she contacted Joseph Dalton Hooker (1817-1911), William's son and successor ${ }^{16}$, to discover that Harvey, in fact, had already named the plant after her, as Brachystelma barberiae, before he died, but had not published the new name. Hooker thus decided to publish a lithograph of Barber's watercolour. The magazine plates were then individually hand-coloured in Curtis's Botanical Magazine in $1866 .^{17}$

This success encouraged Barber to continue using watercolours. She was convinced that watercolours would help her authentically represent what she observed. For an article on birds, for instance, Barber asked 
Trimen to send her stuffed specimens from the South African Museum collection, so that she could illustrate them. ${ }^{18}$ Time and again, she attempted to persuade the editors of the Transactions of the South African Philosophical Society to publish her illustrations, even though the society had never included any plates for financial reasons.

In England, black-and-white line drawings were the accepted means to illustrate scientific publications, as only a few journals could afford to produce colour editions and just a small number of readers had the financial means to buy them. Having witnessed the financial difficulties of his predecessors as well as his own struggles to publish coloured plates, Joseph Hooker avidly advocated for cheaper line drawings, such as in the series Icones Plantarum which his father had launched in 1837. Joseph Hooker had intended to use black-and-white contour-lithography in octavo format in his Flora Antarctica: The Botany of the Antarctic Voyage (1844-1859). Yet, the English government which employed the director of the Royal Botanic Garden Kew and co-financed his publications saw coloured reproductions as a chance to legitimise their investment to the broader public and disseminate botanical knowledge throughout the entire nation. The selling price, however, was so high that his work became unaffordable for most botanists. Due to low demand, he was forced to co-finance the publication. ${ }^{19}$ For him, black-and-white line drawings were thus 'the only model for what a Botanical work should be'. ${ }^{20}$

Barber favoured coloured illustrations but had no influence on whether and how her images were reproduced. In 1867, after reading Darwin's Fertilisation of Orchids (1862), ${ }^{21}$ she, for instance, wrote an article on the pollination of Duvernoia adhatodoides by the large black and yellow carpenter bee (a species of the genus Xylocopa). ${ }^{22}$ She illustrated the moment of pollination in a watercolour in original size and with anatomical sketches of individual sections of the plant to demonstrate the constant structure of both the blossom and the bee's head. Hooker received this article, forwarded it to Darwin and read it to the Linnaean Society on 15 April 1869. Darwin then supported its publication, but Barber remained unaware of their efforts. Presumably, they assumed she had access to the journal, would not require being informed by letter and provided a copy or she was informed but the letter did not reach her. ${ }^{23}$ It was not immediately published, as the president of the Linnean Society, the botanist George Bentham, had doubts about the cost of its illustration, informing Darwin that a coloured plate would be too expensive. ${ }^{24}$ Darwin replied that reproducing two images - one with and one without a bee entering a flower- 


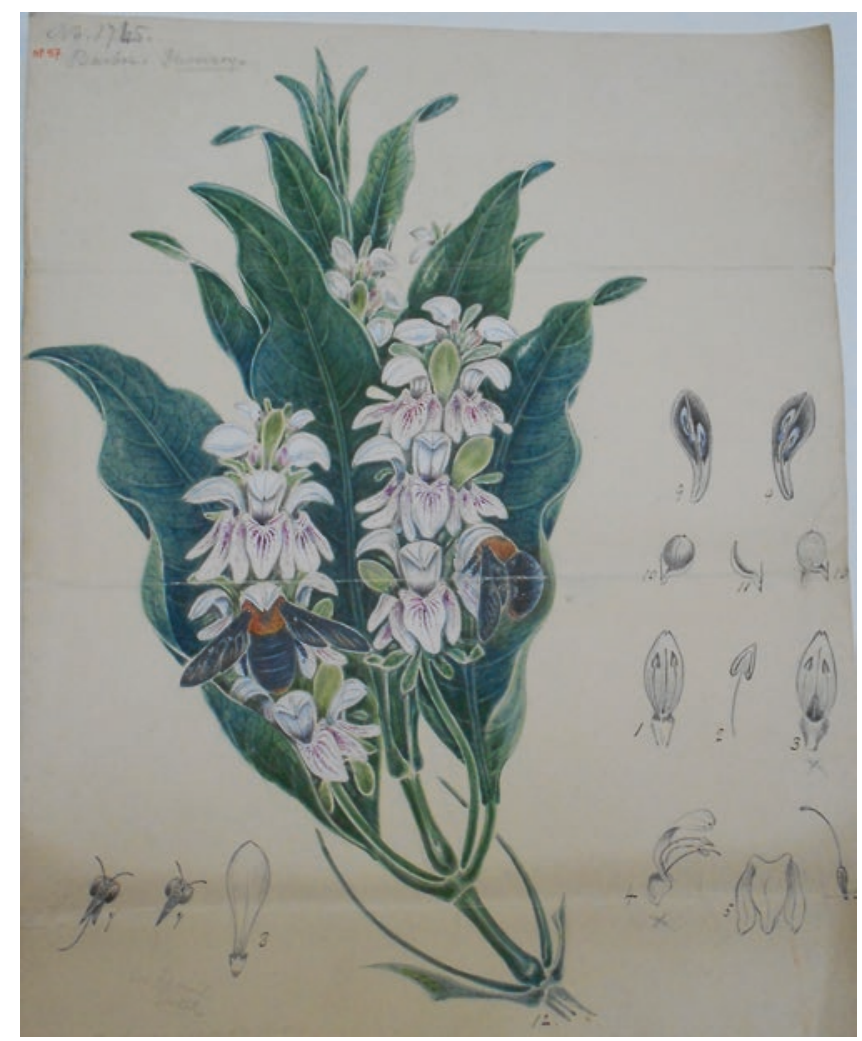

Fig. 4.1 Mary Elizabeth Barber: Duvernoia adbatodoides 1867, watercolour, pencil-ink drawings, SP 57. (@) Linnean Society of London, photographed by Tanja Hammel, February 2012)

on wood would suffice. ${ }^{25} \mathrm{He}$, who realised how important illustrations were for readers of his own publications, predominantly used selected black-and-white frames to make his publications affordable (Figs. 4.1 and 4.2$) \cdot{ }^{26}$

Other scientists in London had different arguments against coloured plates: Hooker aimed to open up botany for less affluent people when John Lindley was the first professor of botany at the University of London. Lindley sought to distance the scientific study of botany from botanising and botanical art in order to raise men's interest in botanical research and 

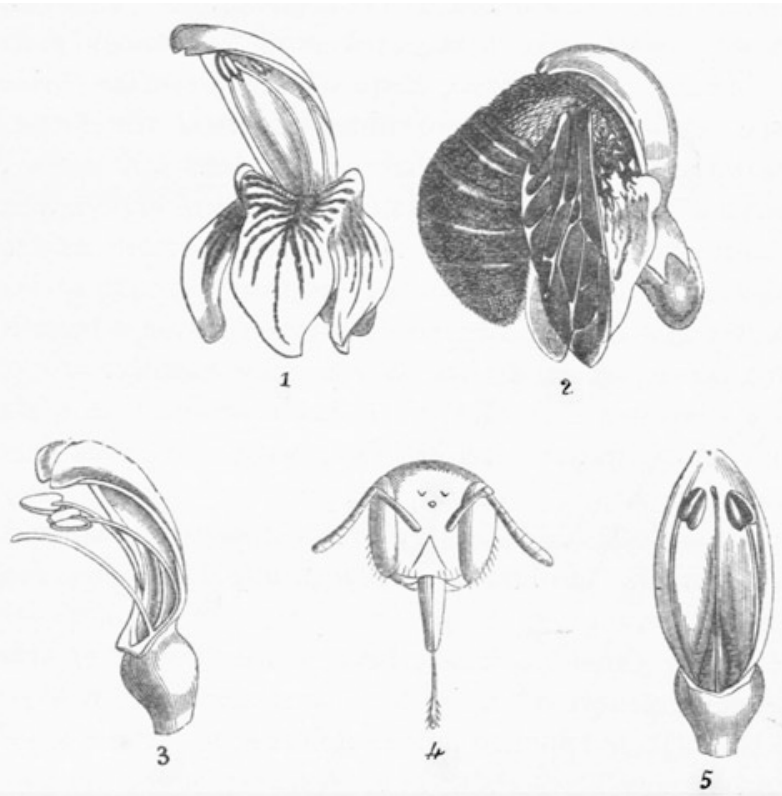

No. 1. A flower of Duvernoia adhatodoides, natural size.

2. The same, with the bee entering.

3. Flower after fertilization has taken place. The lower divisions of the corolla are removed.

4. The head of the bee.

5. Front view of corolla with the lower divisions removed.

Fig. 4.2 Mary Elizabeth Barber: On the fertilisation and dissemination of Duvernoia adhatodoides, Journal of Linnean Society (Botany) 11 (1871), 470, woodcut, $\pm 13 \times 16 \mathrm{~cm}$

distinguish their efforts from women's work. By defeminising botany, Lindley aimed at moving away from the Linnean, aristocratic and polite science in order to shape botany as a rigorous, utilitarian pursuit. He also published Ladies' Botany (1834-1837) to ensure women's educating their children in botany. With this publication, he accorded 'women a niche in botanical practice as mothers and teachers'. He marginalised women as amateur-collectors and leisure time illustrators. ${ }^{27}$ And Bentham was concerned out of pragmatism by rising costs. The Linnean Society itself was an exclusive society with selected members and did not aim to include the broader 
public in its ranks. Like other scientific societies at the time, it had only scarce financial means for the publication of its proceedings and transactions.

Bentham subsequently published black-and-white diagrams of Barber's illustration. ${ }^{28}$ Botanical illustrator and lithographer John Nugent Fitch (1840-1927) printed lithographer of Curtis's Botanical Magazine Walter Hood Fitch's (1817-1892) - his uncle-and British botanist and publisher Alfred William Bennett's template. Bennett is best known for his subeditorship of Nature, an early publisher of photographs and a supporter of higher education for women. ${ }^{29}$ Fitch selected aspects from Barber's illustration to make readers better understand her text, yet the reproduction misaligned the original. ${ }^{30}$ When it came to Barber's illustrations, she thus had no influence on the publication process or the final product.

For Barber, illustrating scientific publications was more than a simple means to supplement her income. In an attempt to assert her scientific standing, Barber hereby entered into another ambivalent space in which professional and lay status overlapped. Like the reading of a scientific paper to the South African Philosophical Society, a space open to 'lay participation', scientific illustration was a sphere that was free to both naturalists and artists, men and women alike. However, professional scientific recognition itself was harder to come by. As a woman naturalist from a peripheral colony, she was even more likely to be excluded from the process of publication.

Information supplied by colonial botanists was constantly absorbed and processed in the metropole. Although the knowledge which they produced had a deep impact on the discipline in general-including the development of new research areas-their role has hardly been acknowledged, ${ }^{31}$ particularly in the case of women experts.

Barber herself experienced this, for example, when she, who had been generally interested in 'strange plants', began observing and experimenting with insectivorous plants in the late $1860 \mathrm{~s}^{32}$ At a time when gothic fiction was popular, the English-speaking world was also much interested in stories about man-eating trees, plant monsters as well as the boundaries and transgressions thereof between animals and plants. Similar to human vampires which were omnipresent in popular narrations, insectivorous plants and others which were in many ways seen as similar to humans triggered human imagination. ${ }^{33}$ That they could act and were predators fascinated authors, botanists and the general public. 
Barber wrote a paper on this topic that she sent to Trimen, which was read before the Graham's Town Natural History Society and printed in the Graham's Town Journal in $1869 .{ }^{34}$ Shortly after, she wrote again to Trimen, encouraging him to criticise her article and asking him to return her only copy. ${ }^{35}$ In a letter to Hooker in September 1870, she mentioned that she had also previously sent him the manuscript and wondered whether it had now been published in the Transactions of the Linnean Society. ${ }^{36}$ Hooker then read it to the Linnean Society on 15 December 1870 in conjunction with a paper on the Californian pitcher plant sent to him by a correspondent in the Sierra Nevada. ${ }^{37}$ A précis of Barber's paper was also published in the Gardeners' Chronicle on 14 January $1871 .{ }^{38}$

Yet, the mysterious manuscript, seemingly Barber's only work in Darwin and Hooker's apparently otherwise meticulous collections, had disappeared. The article is not among her correspondence in the Trimen Correspondence Box at the Royal Entomological Society, as Trimen was asked to return it. It has been argued that Trimen's paper 'eventually made its way to Joseph Hooker'. ${ }^{39}$ It is very likely that Barber sent the very same paper to Hooker, but there is no reference to an earlier letter mentioning the paper, nor could it be traced in Hooker's correspondence or archival box of articles and correspondence related to insectivorous plants. ${ }^{40} \mathrm{In}$ addition, the American literary critic Tina Gianquitto mentions Barber having 'published articles on carnivorous plants native to her locale', but does not provide any reference to Barber's supposed publications. ${ }^{41}$

Botanists were captivated by insectivorous plants from the mid-1870s, and men were eager to make their study a field of research dominated by men. Nepenthes, Sarracenia, Darlingtonia, Cephalotus and the Cape species of Drosera trinervia and the genera Drosera and Roridula-about all of which Barber had written - featured prominently in Darwin's Insectivorous Plants (1875). Barber, however, was not mentioned, but Darwin and Hooker's own observations as well as information supplied by men colleagues were given centre stage. ${ }^{42}$

Shortly before Darwin's book was published, Hooker had chaired the natural history section of the British Association's 1874 meeting in Belfast and had provided a historical overview of investigations into insectivorous plants up until the time of Darwin. In it, he celebrated men who had been interested in 'the most important plants'. ${ }^{43}$ The only woman mentioned in the entire article was the American naturalist Mary Lua Adelia Davis Treat (1830-1923), who was referenced in a side comment. ${ }^{44}$ 
Darwin, on the other hand, did acknowledge Treat time and again. ${ }^{45}$ In fact, he was full of praise for her, describing her as 'more successful than any other observer' in witnessing how Utricularia clandestina ate weak and small prey. ${ }^{46}$ Perhaps decisive here for Darwin were Treat's observations which had previously been published in American journals. ${ }^{47}$ Unlike the local newspaper in which Barber had published hers, Treat's American journals were widely known and read. In addition, Darwin's highly respected Harvard colleague, the botanist Asa Gray, had introduced Treat to him and would have been dismayed had he omitted her. ${ }^{48}$

This exemplary case elucidates how Barber produced information in a field in which many of her counterparts enjoyed more social, economic and scientific capital than herself. Hooker and Darwin, who had initially supported the publication of her aforementioned articles on the pollination and fertilisation of plants which provided crucial corroborative evidence for evolutionary theory (see Chap. 5), did not support the publication of her research on insectivorous plants. This was a field of research in which they themselves wanted to leave a mark and were thus highly selective in whom they acknowledged. In the process, they generally excluded the contribution made by women scientists to their research. Only isolated, 'exceptional' women such as Treat who had a patron and a 'visible' record of publication could win acknowledgement. Just as only one talented African associate could be mentioned by colonial scientists without harming their assumption of racial superiority (Chap. 3), so could just one remarkable woman be acknowledged without threatening the notion of patriarchal privilege in the field.

Barber was interested most in stapelias (e.g. Fig. 4.5), but has hardly been seen as a stapelia expert. From the eighteenth century onwards, European naturalists and explorers became more and more interested in stapelias. During his stay in the Cape Colony between 1783 and 1795, the Scottish plant hunter Francis Masson (1741-1805) cultivated stapelias in his Cape Town garden. These he observed closely and in Stapeliae Novae (1796) described many new species to science. ${ }^{49}$

Important in this line of research was the English plant taxonomist Nicolas Edward Brown (1849-1934). From 1873 to 1914, Brown worked as a botanist at the Royal Botanic Gardens Kew, where he cultivated stapelias. From these, he could observe the individual plants, which also served as models for his illustrations. ${ }^{50}$ Forty-five species of the genus are known today, fourteen of which were named and described by Brown. ${ }^{51}$ While he 
contributed considerably to the taxonomy of South African plants, Brown had never been to South Africa. Yet in 1921, the South African Biological Society awarded the Capt. Scott Memorial Medal to him in recognition of his work on South African flora, while the University of the Witwatersrand awarded him the honorary degree of Doctor of Science in 1932 for his publications in the Kew Bulletin and in Flora Capensis.

He relied on correspondents on site such as Sir Henry Barkly (1815-1898), colonial administrator at the Cape of Good Hope from 1870 to 1877 . Barkly cultivated stapelias in the gardens of Government House, Cape Town, and sent living plants to the Royal Botanic Gardens Kew together with watercolour illustrations by his wife and daughter. ${ }^{52} \mathrm{He}$ collected relatively few specimens himself, but received further material from travellers and collectors. This network allowed him to accumulate an impressive collection that was described by Brown in his Stapelia Barklyanae (1890). Brown's work relied on Barkly's collections and information who in turn depended on collectors and informants all over the Cape Colony.

One of Barkly's collectors and informants was Barber, who is said to have discovered Stapelia glabricaulis and Stapelia jucunda. Stapelia jucunda had been described by N.E. Brown 'from two specimens, both of which came from the area near Douglas. The first to have been gathered was found by Mary Elizabeth Barber, probably between 1869 and 1886, when she lived with her husband on the "diamond fields" near Kimberley'. Her brother Col. James Henry Bowker is said to have been the first to collect and describe Huernia primulina and Stapelia tsomoensis. ${ }^{53}$ The notion of discovery is in itself an ambiguous and debatable term, as it ignores the fact that plants supposedly discovered by Europeans were long-known and -used by Africans in precolonial times,${ }^{54}$ thus privileging forms of Western knowledge production, as Chaps. 2 and 3 discuss.

Among the sixty-eight watercolours donated to the Albany Museum by Barber's descendants in 1903, there are twenty-eight illustrations of plants, nineteen of which are Asclepiadaceae, including fourteen stapelias. It is not known exactly when Barber painted these, but she mentioned them in a letter to Hooker in 1877 in which she asked where they would be 'most appreciated and most useful'. She was afraid to leave her paintings 'in the wilds of South Africa, and one of these days when I am dead and gone they will be thrown away or given to children to play with perhaps' ${ }^{55}$ However, Hooker was not interested in stapelias and did not ask her to send them to the Royal Botanic Gardens Kew. Eight years later, she 
reported to Trimen that she had been 'very busy painting some Stapelias which have just come out into blossom in Dr Becker's garden'. ${ }^{56}$

Indeed, Barber seems to have visited German medical practitioner Hermann Franz Becker (1838-1917) frequently between 1880 and 1885 . He had come to South Africa in 1869 and moved to Grahamstown in 1874, where he started a private practice after working as a surgeon and spent the rest of his life collecting insects, shells and algae. ${ }^{57}$ She painted the stapelias in his garden which had hitherto not been in her collection of stapelias growing in Albany. ${ }^{58}$ Still hoping for recognition, she produced a series of life-size, watercolour stapelia portraits including their 'situation, direction, scale, and shape'. ${ }^{99}$ Some of these accompanied her 1888 article on the genus that she sent to the Royal Botanic Gardens Kew; yet, neither the article nor her illustrations were published during her lifetime. ${ }^{60}$

The stapelia illustrations, which Barber sent to the Royal Botanic Gardens Kew, were transformed into lithographs by Mathilda Smith (1854-1926). Smith was Hooker's second cousin and was employed as Kew's first official botanical illustrator. Between 1878 and 1923, Smith created over 2300 plates for Curtis's Botanical Magazine and 1500 plates for Icones Plantarum. She was part of the establishment and was eager to remain so. Fashioning herself as 'the exceptional woman' in a field dominated by men, she had little interest in promoting other women. She may have feared that women such as Barber would challenge her for her position. In order to understand the structure of the plant, she chose one particular section of Barber's originals and copied these in watercolour before illustrating them with line drawings for Hooker's Icones Plantarum (1890), as the archival sources at Kew's Library, Art and Archives demonstrate. ${ }^{61}$ Barber, however, was not acknowledged in the final reproduction. ${ }^{62}$ Thirty-six years younger than Barber, Smith enjoyed an official position as a draughtswoman and would later be awarded the Silver Veitch Memorial Medal by the Royal Horticultural Society as well as becoming the second woman elected to the Linnean Society. ${ }^{63}$

While Barber's stapelia research has largely been ignored, Barkly and Brown have been remembered as pioneers in the field, and Barber has not even been acknowledged as one of their most important informants and collectors. Equally ambiguous is Barber's reception among current botanists: South African systematic botanist Peter Linder, based at the University of Zurich, evaluates Barber as an important collector and informant, while mathematician and stapelia-expert Peter Bruyns based at the University of Cape Town sees her as 'one of several such collectors and, as 
such, not an especially prominent figure'. ${ }^{64}$ As such, the examples from Barber's contributions to botany illustrate in an exemplary manner how gender, class and location impact upon Barber's scientific legacy.

\section{How Barber's Local Lepidopterist Network Lent Her WINGS}

Barber's explorations of the natural world around her saw her participate in local collecting networks which also included relatives. The Bowkers were a close-knit family, who regularly corresponded and collaborated with one another. Mary's parents, her eight older brothers and her younger brother and sister regularly organised family gatherings on special occasions, such as Christmas, and frequently visited one another on their respective farms. ${ }^{65}$ Mary's brother, Bertram Egerton, remembered their parents as 'the best two people' whom he had ever known. Their mother, in particular, seems to have been an affectionate and caring person, who was deeply involved in her children's lives. ${ }^{66}$

Particularly engaged in scientific pursuits were Thomas Holden and James Henry Bowker, who were fascinated by entomology, botany and archaeology. ${ }^{67}$ The latter, whom Barber called Henry, was to be a lifelong companion for her, with whom, as she later recalled, she 'always worked together in collecting'. Their relationship exhibited care and respect; Henry had never married and Barber lived with him when they were old. During their collecting partnership, Barber ensured he was acknowledged in scientific publications, forwarded literature to him and explained to Joseph Hooker in a letter that she only wished for her 'share of note' from their work. ${ }^{68}$ She sent more than 1000 plant specimens which they had collected to Harvey at Trinity College Dublin 4.3.

Henry was mainly interested in Lepidoptera and over the years became probably the leading collector of butterflies in South Africa. He was almost never seen without his net (see Fig. 4.3) and became known as 'Butterfly Bowker'. It was even reported that, on at least one occasion, he had downed weapons in the midst of a fierce battle in order to capture an unusual butterfly. ${ }^{69}$ Bowker had been part of a group of Royal engineers, which became known as the Queen's Cross Expedition. They were sent to erect Queen Victoria's cross on the spot where the late Napoléon, Prince Imperial $\left({ }^{*} 1856\right)$ had fallen in the Anglo-Zulu War on 1 June 1879. The expedition had taken place prior to the visit of Eugénie de Montijo, wife of Napoleon III and empress of France between 1853 and 


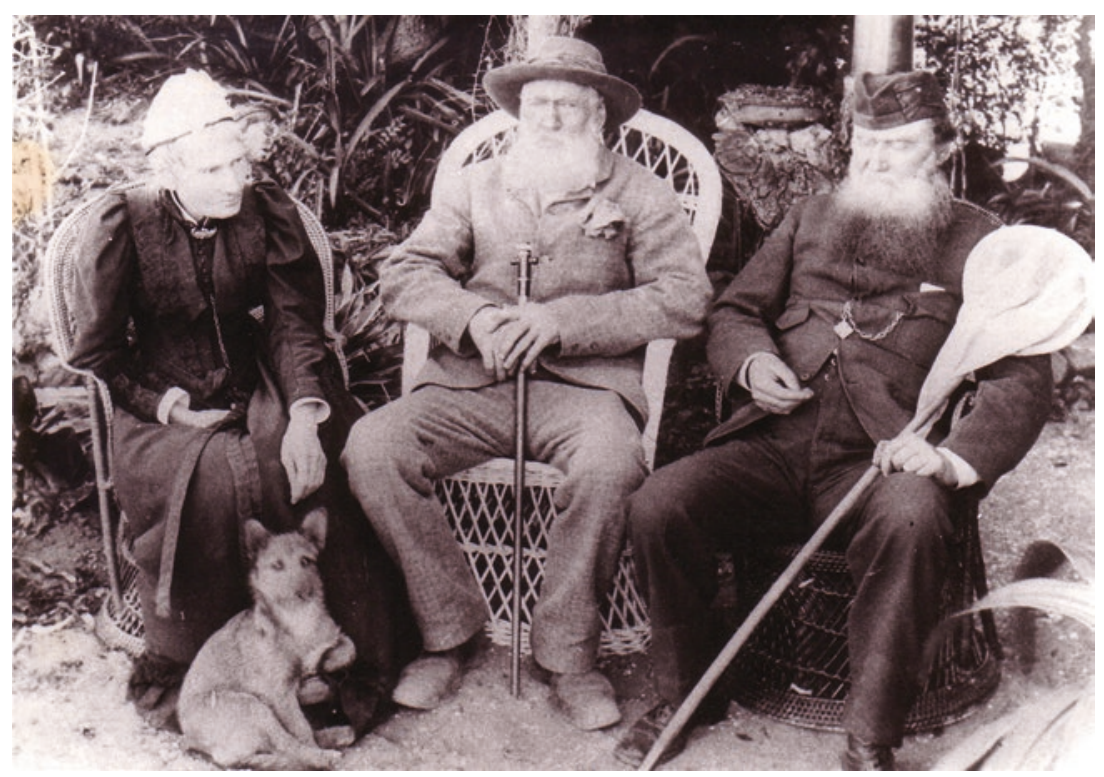

Fig. 4.3 Mary Elizabeth Barber, probably Thomas Holden Bowker, and James Henry Bowker ca. 1880. (Photographer not known, taken on a veranda with lilies, aloes as well as geological artefacts in the background. (C) HM, SIM PIC 5643/ii, photographed by Tanja Hammel, April 2014. (C) History Museum, Albany Museum Complex. All rights reserved)

1870. As Bowker knew the grave, the memorial and had a high reputation, he was chosen to show her the site. Apparently, the empress was flabbergasted when she saw Bowker with his butterfly net in hand presenting to her the grave of her son. ${ }^{70}$ In 1883, the British botanical oil painter Marianne North met 'Colonel Butterfly', as he also became widely known, in Durban.

Bowker was in close contact with Roland Trimen (1840-1916). Trimen was born in London and educated at Rottingdean and then King's College School. His younger brother, the botanist Henry Trimen $\left({ }^{*} 1843\right)$, was the editor of the Journal of Botany in London and the director of the Botanic Gardens at Peradeniya, Ceylon, from 1879 until his death in 1896. For health reasons, Roland came to the Cape of Good Hope in 1858, at the age of eighteen. Initially, he spent time cataloguing and arranging the collection of Lepidoptera in the South African Museum as 
a museum assistant. After passing the civil service examination in July 1860, he joined the Cape public service, moving up through the auditorgeneral's department and the office of the colonial secretary as a private secretary. As curator of the South African Museum from 1872 to 1893, Trimen could not conduct much fieldwork. As a result, he appreciated the efforts of his 'friend Colonel' Bowker, to whom he had been introduced in 1866 by his superior at the museum Edgar Leopold Layard.

Bowker hated writing and informed Trimen that he would most happily share all his knowledge in conversation. He did not publish anything on butterflies, but Trimen did so on his behalf. ${ }^{71}$ The two occasionally met in Cape Town, Albany and London. Nevertheless, he did write about 190 letters to Trimen between 1861 and $1894 . .^{72}$ Indeed, Trimen felt that Bowker had contributed so much to his work throughout the course of his career that he made him the co-author of the three-volume South African Butterflies (1887-1889). Bowker, who had conducted entomological research in 'Kaffraria, Basutoland, Griqualand West, Natal and Zululand' for twenty-seven years, during which he described and collected forty species and one genus of Lepidoptera new to science, provided the South African Museum with numerous specimens. For all his efforts, Trimen recommended him as a fellow of the Linnean Society in $1889 .{ }^{73}$

Trimen also supported Barber, became her friend and entomological patron, after she began corresponding with him in 1863. She communicated her brother's insights to him as well as her own. Twenty-two years younger than Barber, Trimen held the relatively lowly position-relative, at least, to those of Barber's other correspondents Hooker and Harveyof a museum assistant, when she first contacted him. Her brother introduced her to Trimen as an illustrator, and she turned to him as her interest naturally shifted from plants to butterflies who fed upon plants she had been interested in. They corresponded until 1888, which resulted in more than one hundred letters and more than twenty watercolours and inksketches. ${ }^{74} \mathrm{He}$ visited her on at least one occasion. They collected Lepidoptera together in Albany in $1870 .^{75}$

Unlike other disciplines within the natural sciences, which were undergoing a (at times slow) process of professionalisation, entomology was seemingly open to all classes as well as both sexes. Indeed, the Entomological Society of London, which was founded in 1833, was known for its openness to everyone and the low subscription fees which explains why the majority of its members were working-class entomologists. ${ }^{76}$ Women were accepted from its outset, unlike the Royal Society which only accepted 
them in $1945 .{ }^{77}$ By 1900 , the small entomological society in London had thirteen women members. ${ }^{78}$ Trimen, who had served on the council for several periods and was president in 1897 and 1898, fully supported this policy to keep entomology open to everyone.

There had been women entomologists, such as Maria Sibylla Merian (1647-1717), who had lived in Frankfurt, Nuremberg, Amsterdam and West Frisia and had become famous for her two-year journey through Surinam in 1699 after which she had published her magnum opus Metamorphosis insectorum Surinamensium. Although she had shown what women entomologists could achieve, one hundered and fifty years passed after her death before a few women born in the earlier decades of the nineteenth century, such as Barber and the Irish entomologist Mary Ball (1812-1898), entered the field and made vital contributions. ${ }^{79}$

Travelling became easier with the expansion of the railway network both in Europe and the colonies and natural history studies developed into an important means for settler communities to embed themselves into their adopted homelands. Entomology offered the opportunity to engage in a secular sphere at a time when Christian congregations were increasingly divided both in the metropoles and colonies. These factors encouraged women, such as Barber's nieces, to engage in entomology, yet they could not make themselves known and were unaware of possible role models such as Merian, who long forgotten, have only started to attract the attention of women historians in the last two decades. ${ }^{80}$ In addition, a number of factors discouraged women from pursuing entomology. The need for their help in the domestic sphere, on farms, as governesses and nurses left little opportunity to practise science. Furthermore, women scientists could only distinguish themselves when they had patrons and support, as Barber in Trimen or Ball in her brother who read and published her work.

Trimen also provided Barber with the equipment required for entomological research. He sold and sent her paintbrushes, paint and 'cruel looking entomological pins' which replaced the unscientific needles that she had previously used. ${ }^{81}$ As research literature, Barber took Harvey's Genera of South African Plants, Trimen's Rhopalocera Africae australis and Layard's Birds of South Africa wherever she went. ${ }^{82}$ When her sons took her reference works with them on expeditions or a fire destroyed them in Kimberley, Barber immediately asked Trimen to provide her with new copies. She was even prepared to suggest to Trimen that he steal copies for her, if none was available for purchase, an indication of how important 
these standard works were for her. ${ }^{83}$ Yet she later knew that many of these were not up to date. She, for instance, wrote in 1885: 'My birds are named from Layard's old bird book [published in 1867], being the only one that I possess, probably they may be wrong? But what could I do?'84

Like the standard works by Layard and Harvey, Barber also influenced the contents of South African Butterflies by insisting that details of each butterfly's habitat and the plant(s) which the pupae fed upon, when known, should be included in the descriptions, illustrations and butterfly names. ${ }^{85}$ As one of its founding members, Trimen made Barber a member of the newly established South African Philosophical Society in 1878. He praised her 'many-sided mental powers', 'loving true-heartedness', 'equanimity, cheerful self-reliance, fine sense of humour, and cool courage'. ${ }^{86}$ The qualities which Trimen foregrounded show that he valued her as a colleague, co-worker and friend whose achievements in science he deeply respected. Yet, he would not have praised a man colleague's 'loving trueheartedness', which indicates that he perceived her most of all as a woman.

To provide him with as much information and as many specimens as possible, Barber encouraged young settler women in her area to collect local butterflies. She also aimed to educate them and founded a reading society of fifteen subscribers for which she organised the provision of scientific literature from Cape Town and abroad. ${ }^{87}$ During the Seventh and Eighth Cape-Xhosa Wars in the Albany district, many men were absent as they were on the battlefields. This explains why Barber, who, at the time, was farming for her family's subsistence, educating her children and spending time with her relatives, could play an influential role in the lives of her nieces and motivate them to contribute to science. Barber's young daughter, Mary Ellen (1853-1938), was of valuable assistance in catching butterflies and rearing them from caterpillars. ${ }^{88}$ The daughters of Barber's brother, Bertram-Mary Ellen White (1840-1915) and Fanny Bowker (1850-1940)—were vital collectors and informants at Table Farm and Pembroke near King William's Town, respectively. ${ }^{89}$ White also helped Barber to illustrate and is said to have been among a number of 'enthusiastic' but 'quite mediocre' white botanical artists in the Cape at the time. ${ }^{90}$ Yet, her remaining watercolours of birds and flowers and her participation in the Port Elizabeth Art Exhibition in 1861 indicate that she had considerable talent which was honoured locally during her lifetime. ${ }^{91}$ Besides Barber's relatives, the governess to the younger Bowker children, Sophia Beddoe $\left(*\right.$ c. 1835), who arrived in 1863 from England, ${ }^{92}$ and her sister, Emma Beddoe $(*$ c. 1834) helped her collect, usually at her brother 
Bertram's farm, Oakwell, where Sophia worked. Many of these young collectors did not correspond directly with Trimen but informed Barber of their finds and provided her with material which she could forward to him. Yet, Barber made sure that Trimen acknowledged each informant individually. ${ }^{93}$

Barber was not the only woman entomologist in the area. Bliss White (née Atherstone, 1823-1907), sister of William Guybon Atherstone, was also interested in wasps, beetles, arachnids, plants, shells, rats, bats, birds, snakes, lizards, tortoises and small mammals. After marrying, she spent most of her life on Brakkloof, about thirty-five kilometres northwest of Grahamstown, where she had eight children. For twenty-one years, she was one of the Albany Museum's key collectors, and her plant, insect and animal specimens are still part of the museum's collection today. Yet, it remains unclear whether and how Barber and White collaborated. ${ }^{94}$ White seems not to have been in contact with Trimen and only shared her ideas locally.

Barber's local network was by no means exclusionary one of women. She also received information from her sons. Frederick Hugh Barber went on an expedition by ox-wagon to the Victoria Falls in 1875 and to Matabeleland in 1877-1878, during which he painted the passing sights and kept an expedition journal. ${ }^{95} \mathrm{He}$ also helped Barber create ornithological illustrations and was acknowledged as an informant in her scientific articles. ${ }^{96}$

Little is known about her husband Frederick William Barber's (1813-1892) impact on her career. But he, the youngest of seven sons of Thomas Barber from Nottingham, a portrait painter of many of the aristocracy of the Midlands, ${ }^{97}$ seems to have been well educated at Olney and Eton College. He regularly wrote articles on various subjects for newspapers, was interested in agricultural matters such as the fertility of soils and was described as a 'somewhat retiring, studious man'. ${ }^{98}$ Although he seems not to have directly supported his wife's scientific research by encouraging her to publish, become a member of scientific societies or obtain a paid position in science, he shared an interest in science and tolerated her timeconsuming research.

The more Barber and her co-workers were acknowledged by Trimen, the more self-confidence she gained. As supportive as Trimen and his colleagues at the Cape were of Barber, it is striking that of her sixteen published articles, those published in South Africa remained ambiguous as to her sex, with only her initials 'M. E.' recorded in the author's column. ${ }^{99} \mathrm{In}$ 
contrast, articles which she published in England were released under the name of 'Mrs. Barber' or 'Mrs. M. E. Barber' ${ }^{100}$ Not all of Barber's collaborations were as fruitful as the one with Trimen. She also met with considerable difficulty and resistance from other men in her scientific pursuits.

\section{The Marginalisation of the First South African WOMAN ORNITHOLOGIST}

Curator of the South African Museum and its leading ornithologist, Edgar Leopold Layard, sixteen years older than Trimen, credited Barber and David Arnot, a Khoekhoe descendant, ${ }^{101}$ for their information on species of birds, birds' behaviour and habitat, but also displayed an adherence to race and gender hierarchies.

He dedicated Birds of South Africa to his wife, his 'loving companion and helpmate in [his] labours' and named an apparently new species of an South African pipit (Anthus Calthropae) after Barbara Anne (known as Annie) Layard in 'memory of the faithful companion of [his] labours for upwards of 20 years, who has aided [him] with pen and pencil, and shared the pleasures [he has] experienced in the study of the works of Nature'. ${ }^{102}$ Yet, the pipit had already been named. His wife was an accomplished artist and ornithological co-worker, whose work and career were gradually subsumed under his reputation and public persona, with consequently little known about her today. ${ }^{103}$

Barber and Layard closely collaborated while he compiled Birds of South Africa from the 1850s to the mid-1860s. Layard knew Barber's brothers well. They had also met personally, and much of their social circle overlapped. He visited the Barbers at Highlands at least once with Trimen in February 1870 and mentioned this visit in an article published later that year. ${ }^{104}$ Thomas Holden Bowker was in close contact with Layard, as Chap. 7 shows when elaborating on their exchange on archaeological findings. Layard was the godfather of his fourth child Mary Layard Bowker, as her second name reveals.

In 1868, Barber asked Layard, who was about to leave for England, whether he could take a paper that she had written on the basis of James Henry Bowker's notes with him for publication there. This he did, but falsely published it under the name of 'Mr Layland', which was supposed to be a typo for Layard. ${ }^{105}$ According to Barber, in 1869, the article was thus published in 'German newspapers and scientific Journals and also in 
many publications in England and elsewhere with his name to it'. Barber could not understand how this 'came to pass', as she claimed to have requested Layard to send the copies off under Bowker's and her name, to which he had promised that 'the saddle was put upon the right horse'. ${ }^{106}$

This incident permanently soured their relationship. In 1870, she, for instance, ridiculed Layard for mistakenly arguing that the stone grasshopper of Grahamstown, which she had described in 1868-1869, was winged. ${ }^{107}$

At the same time, Barber sensed that there was tension between Layard and Trimen. She wrote to Trimen in April 1871 that she had been surprised when she heard that an amateur artist and self-taught geologist Henry William Hull Coleman Piers (1813-1887) would become Layard's successor as curator of the South African Museum. She found it a 'folly' 'to put a man in, who knows nothing of science', and interpreted this as a conscious decision on the part of Layard to exclude Trimen. She further promised to tell Trimen about Layard's dishonesty, although only when they met in person, as she did not want to publicly engage in the debate, claiming that it was generally assumed that women were 'fond of scandal' which she absolutely loathed. ${ }^{108}$

Barber might have hoped that her career would experience a boost if Trimen became the curator of the museum, which could be the reason behind her interest in his potential promotion. Her constant fight against gender stereotypes and misrecognition made her very sensitive to any plagiarism and misquotation of her work. Barber saw Layard as an illegitimate gatekeeper, who did subsume her information to fashion himself the founding figure of South African ornithology, while pushing her to the margins of the discipline.

Emil Holub, in contrast, was to make sure that her ornithological work would not be forgotten. He had worked as a doctor in a tent at Du Toit's Pan while she was there and had met her son Fred near the Klamaklenyana springs while both were on expedition. When he returned to Kimberley from an expedition, Fred showed Holub his mother's ornithological illustrations. Holub was impressed by Barber's keen observatory skills, her 'artistic power' and publication record. ${ }^{109}$ Her illustrations impressed him so much that he promised to 'celebrate' them 'all over Europe' and 'blow [her] trumpet at all the scientific societies', as her sons gently teased her. ${ }^{110}$

Barber, however, was dismissive of Holub's talents, arguing, for instance, that while he had certainly accumulated impressive financial 
means and scientific collections, she did not admire his skills as a traveller and was certain that in the interior of Southern Africa he would 'come to grief amongst the natives'. ${ }^{11}$ As such, she had little faith in Holub's knowledge of the country and, as a settler, felt her own knowledge and life-long experience to be vastly superior. However, she appeared jealous of Holub's financial security as well as his fame and recognition.

Indeed, men in general, she felt, enjoyed endless opportunities to travel, and voyages were career-making. When she read in a newspaper article in 1883 that botanist Harry Bolus, entomologist Roland Trimen and traveller Emil Holub 'were on the point of crossing the Dark Continent from end to end' and that 'the scientific world were looking forward to great discoveries from so learned a staff of celebrities', she saw her chance. She asked Trimen if she could join as a 'scientific artist', an occupation that was most readily accepted as appropriate for a woman within science at the time and hoped she could enjoy men's privilege of travelling. She went on to request how many wagons she could take for conveying her colours, canvases, drawing papers and small library of reference works or whether the expedition would supply her with all necessary equipment. ${ }^{112}$ The proposed expedition, however, would never occur. As she had no opportunity to travel on her own, she had to stress her expertise as a local expert.

When Holub arrived in Vienna, he gave a lecture on South African avifauna in which he praised Barber's work. ${ }^{113} \mathrm{He}$ spoke with August von Pelzeln (1825-1891), who had been the custodian of the Austrian Imperial Collection of birds and mammals in Vienna since 1869 as well as the secretary of the Ornithological Union of Vienna. With few ornithological societies at the time, this seems to have been one of the oldest and the most renowned. Von Pelzeln had already known Holub before Holub's return. On 10 February 1882, he followed Holub's suggestions of making Trimen and Barber corresponding members of the society. In the society's transactions, Barber was first mentioned as 'Herr' (Mr), then as 'Fräulein' (Miss), from Cape Town. Considering that by then Barber had been married for forty years, was sixty-four years old and had never resided in Cape Town, the society knew extremely little about her. Given that she could not read their German transactions, Barber in turn would have known little more about the society herself. ${ }^{114}$

Barber did not know how to react to her election as a fellow of the ornithological society in Vienna and asked Trimen to write her an acceptance letter. She gave him instructions to ask someone else to transcribe it 
so that the society would not find out that it was his handwriting. ${ }^{115} \mathrm{He}$ seems to have done so, for there is no further mention of it in her letters to him. This shows how much influence she had and how strong their friendship was.

This honour increased Barber's self-confidence. She praised Holub for doing more for her than any of her 'countrymen', an indication of her disappointment at the lack of appreciation she received. While she had seen many of her articles published by different societies, she was frustrated that she was being ignored by scientific societies. As she claimed to Trimen, 'they have never thought me worthy of having [been] made a corresponding member, perhaps they do not care for having ladies amongst them, I have often thought that if I had been a man I should not [have] been excluded'. ${ }^{116}$ As this discouraged letter written ten years after Trimen had been promoted to become Layard's successor and shortly after their election to the Viennese society indicates, she had not gained further recognition through Trimen as she had hoped for or even expected. She was convinced that she suffered under the exile from science because she was a woman.

Indeed, the South African Philosophical Society appears to have been the only society at the Cape that accepted her as a corresponding member, while, in Britain, the Linnean Society of London, within which Trimen was also influential, would continue to exclude women from becoming members for another thirty years. The quoted letter is one of very few passages in Barber's writings in which she discussed the omission of women. As she got older, Barber became more independent and ambitious and sought acclaim more eagerly. Her critical statement above was addressed at the scientists at both the Cape and in Europe who excluded her, such as Layard and her colleagues in Grahamstown and London.

The muted contemporary reaction to Barber's rich record of collaboration has had a deep impact on how her legacy has been remembered over the course of the last century, resulting in her marginalisation and complete exclusion from the history of ornithology in South Africa.

Given that there was no ornithological society at the Cape during her lifetime - the South African Ornithological Union was only formed in 1905-and no large network of ornithologists in the 1860s, her potential to influence contemporary science was reliant on Layard's efforts. Despite the mutual information exchange from which he benefited, he never reciprocated her efforts by recognising Barber in the public scientific sphere or by enabling her to publish an ornithological article or illustration in Ibis, the then leading ornithological journal. 
Barber has subsequently remained unacknowledged as the first woman ornithologist in South Africa, and her African associates were silenced altogether. ${ }^{117}$ Her marginalisation had much to do with her gender; Africans' with their race. They were all disregarded due to the contemporary professionalisation of the discipline and the concomitant contempt in which amateur scientists were held. Given the difficulties which women scientists experienced, it could be assumed that they collaborated with each other in an effort to combat patriarchal gate keeping.

\section{Collaboration and Competition Among Women SCIENTISTS AT THE CAPE}

Barber was one of a number of women scientists at the Cape at the time, but her career was quite different to those of her younger colleagues.

Compared to the Cape Town-based philologist Lucy Lloyd, who, out of anxiety and lack of self-confidence, often self-effacingly published her 'Bushman Work' under her brother-in-law Wilhelm Bleek's name or under the nom de plume $L$; Barber, sixteen years her senior, was self-assured and never openly displayed any signs of self-doubt. ${ }^{118}$ Lloyd was one of very few contemporary women with a paid position in science. After Bleek died, Lloyd was offered his position as curator of the Grey Collection at the South African Public Library at half his salary. She initially did not agree but eventually reluctantly accepted the position, which she held from 1875 to 1880 . Ultimately, however, Lloyd would stand up for herself in a starkly conservative intellectual environment which was dominated by hostile figures such as superintendent of education Sir Langham Dale. In the process, she became a powerful voice in Cape Town's intellectual community. Her services were suddenly terminated in 1880 because a man candidate for her position had suddenly become available. This was the trader and Nama linguist Dr Theophilus Hahn. Hahn was soon criticised for his unsatisfactory work as a librarian and moved to Stellenbosch in November 1883. ${ }^{119}$ Lloyd and the trustees of the Grey Collection took the case to the Supreme Court.

Another woman who gained a similar post after a relative's death was Mary Glanville (*1861), who, for two years prior, had been her father's assistant while he was the curator of the Albany Museum in Grahamstown. Glanville was appointed curator on his death in 1882 and, in this role, oversaw the museum's move to new premises and its ever-growing collection of specimens. In turn, the growth in the museum's collections saw 
the number of visitors rise from 2000 in 1883 to 10,000 in $1886 .{ }^{120}$ After organising the Queen Victoria Jubilee Exhibition in 1887, which attracted 25,099 visitors, Glanville was plagued by ill health, until she died suddenly in 1888. In her obituary in The Economist, the success of the jubilee exhibition was attributed to her 'untiring zeal, genial courtesy and indefatigable exertion'. ${ }^{121}$

Lloyd and Glanville were both unmarried and had no one to provide for them. This might have made it easier for them to justify their need for these paid positions and to succeed the relatives with whom they had previously closely collaborated. For the men in power such as Dale and Atherstone, Lloyd and Glanville represented well-qualified interim replacements who were already familiar with the collections and were prepared to work at a lower salary.

Women who had not previously held an assistant curatorship or collaborated in a project such as Glanville and Lloyd were not granted position and recognition, but received a consolation package: pseudo-guardians, who stepped in as patriarchal replacements to allow them to continue their work and receive a wage in lieu of what they had been given by their dead relative. Those such as Mary Treat, who were separated from their husbands, did not enjoy the same benefits and never held official positions in science. Treat was based in New Jersey and contributed to the disciplines of entomology, ornithology and botany. After separation from her husband in 1874, she supported herself by publishing popular science articles. Over a space of twenty-eight years, she authored seventy-six articles and five books. ${ }^{122}$

With much in common and both being residents of Grahamstown in the mid-1880s, it could be assumed that Barber and Glanville collaborated. Yet, the two entomologists were rather competitors, as the interesting case of their papers on insectivorous birds in 1886 demonstrates. Glanville's main research interest had always been agricultural pests, and the English economic entomologist Eleanor A. Ormerod $\left({ }^{*} 1823\right)$ praised her as 'highly gifted' for having laid the foundation for the 'study of crop pests of the Eastern Province' and for having provided her with the 'best specimens'. ${ }^{123}$ Glanville opened the discussion with her paper on 'Our Foes and Friends among the Birds', which she read to the Natural History Society on 25 February and published in The Graham's Town Journal on 1 March. ${ }^{124}$ After listing the birds which were both helpful and destructive to the local farmers, she concluded that small insectivorous birds required protection from those who shot them to obtain their feathers for ladies' 
bonnets. In the discussion that followed the presentation of the paper, farmers were encouraged to prohibit boys from killing birds in their orchards, but ornithologists were not dissuaded from continuing to collect. ${ }^{125}$ The publication coincided with the foundation of the Audubon society, an organisation for the protection of wild birds and their eggs, by American editor of Forest and Stream George Bird Grinnell. ${ }^{126}$

A few months later, Barber, who was forty-three years older than Glanville, entered into the debate with a public reading of her paper on 'A Plea for Insectivorous Birds' at the Eastern Province Literary and Scientific Society. The paper was read by Mr. Fairbridge, a member of the society, on 15 July 1886. The society had its own reasons for putting on the reading, such as recruiting new members; in so doing, it marketed itself as nonelitist and inclusive by allowing the public-namely, white settlers-to attend meetings for a small financial contribution. It had announced the event, which they regarded as 'of keen interest to the whole colonial community', a week earlier. This was unusual, as monthly reports on past events were customarily published in the local newspaper. The society, founded by William Guybon Atherstone, had originally focused on medicine and literature, and its collections had been the basis of the Albany Museum. It aimed to position itself as an organisation that supported the 'amateur study of local science', welcomed innovative thinkers and recognised urgent scientific imperatives in the region.

A second point on their agenda was an amalgamation with the Albany Natural History Society. That the two societies often discussed identical subjects is evidenced by Barber's and Glanville's papers. An amalgamation would have allowed the Albany Natural History Society to save both space and a secretary's salary and would have ensured the Albany Museum a constant supply of new collections and information as the members of both societies would provide data.

On 16 July, when Barber had her paper read, the attendance was reported to have been low. The paper was also published in the Journal on 17 and 19 July as well as in pamphlet form. The reasons given for the publication of the pamphlet are striking, as they do not include the protection of birds but rather the hope of bringing 'the Society much credit, and the thanks of all true horticulturalists'. ${ }^{127}$

Though Barber substantially added to Glanville's arguments, no response by the latter seems to have been forthcoming. Glanville seemingly ignored the laywoman Barber and did not enter into either a private 
or a public scientific exchange with her on the subject. They did not publicly compete, but in publishing their papers in the local newspaper, their men colleagues turned them into competitors, two experts conducting research on the same topic.

All women scientists at the time (whether in paid positions or not) seemed concerned with leaving their own mark on their disciplines and were not prepared to join forces with other women scientists to fight for more recognition for women in science. The discussion of insectivorous birds in Grahamstown also illustrates that rather than supporting women and accepting them in scientific societies, Barber and Glanville's patriarchal colleagues played them off against one another. The Grahamstown Natural History Society faltered in 1887. The Eastern Province Literary and Scientific Society revived, in 1892 amalgamated with the Albany Natural History Society (1867-1875, refounded in November 1890) and formed the former's Natural History Section. ${ }^{128}$

Another case in point to elucidate women in science were as competitive as men is the British botanical artist Marianne North's relation with women botanists at the Cape. A close reading and comparing of North's oil paintings and diary entries with Barber's watercolours provides insights into how North created her renowned works of botanical art. It provides insights into North's intervisuality-the shaping of an image by reference to other images.

After her mother's death, North had accompanied her father Frederick, the Liberal member of parliament for Hastings, on his business travels. After his death, she travelled the world on her inheritance, illustrating the Empire's flora for the British public. Her paintings can be viewed in her gallery at the Royal Botanic Gardens Kew that she had donated and opened in 1882. ${ }^{129}$ In an attempt to make up for the absence of images from Africa, North travelled to South Africa in 1883 and added an additional room to the gallery upon her return. ${ }^{130}$

While she was travelling, she kept a journal, and the passages on her time in the Cape paint an interesting picture of how she perceived herself as superior to local botanical artists, whom she regarded as 'colonial imitators'. ${ }^{131}$ With the extra cultural and economic capital which she possessed in the form of her metropolitan background, her higher level of education (e.g. art courses) and the political power which she enjoyed through her father's political contacts, North epitomised metropolitan privilege in comparison to the relatively powerless situation endured by many settlers and British women at the Cape. 
North saw Barber as a competitor and criticised her work. Initially, North wrote that she was 'delighted' when Barber entered her room one day while she was painting, having encountered Barber's name- 'the great authority on all sorts of natural history', as North described her-repeatedly since her arrival in South Africa. North recorded in her diary that Barber's illustrations were 'done much in the way old Anne North did her flowers in the year I was born [1830]'. ${ }^{132}$ She then continued to ridicule Barber's old-fashioned style and emphasised the difference between Barber's white paper and her own canvasses.

Experts, however, have described Barber's paintings as 'botanically sound'. ${ }^{133}$ Barber organised paper locally, but depended on Trimen to send her paintbrushes from Cape Town, which he in turn might have ordered from Europe. ${ }^{134}$ Colours were not mentioned, but Barber produced her own ink from plants. ${ }^{135}$ We can assume that Barber faced difficulties organising adequate paints. Colours faded over time due to climatic and storage conditions.

Barber was not the only colonial expert that North disparaged. North described Katharine Saunders as a 'clever little wife [...] in a waterproof cloak, looking like a figure out of Noah's ark. She was always most earnest about everything she did, and spent hours trying to puzzle out the names of every little weed'. ${ }^{136}$ North thus felt superior as an unmarried, independent traveller and suggested that while botanising was hard work for Saunders, it came naturally to herself. She further recalled having instructed Saunders on how to paint with oils, but the former did not like this approach and remained a watercolourist, which, according to North, was not only less suitable for representing plants, but also less artistic.

North also met Bishop of Natal John William Colenso's wife Frances and did her 'best to disentangle her artistic difficulties, and give her courage to go on painting from nature. The companionship of sweet flowers would have done her more good than sickly sentimental phantoms of high art', North commented unflatteringly. Colenso was said to have been inspired by English painter Edward Burne-Jones (1833-1898), a wellknown representative in the second phase of Pre-Raphaelitism, but had difficulties living up to the movement's standards. North suggested in this regard that Colenso lacked the talent, access to artistic circles and education to be a successful painter. For North, there was a distinction between flower painting and botanical art. This corresponded to the divide between amateurs, like Colenso and her South African counterparts, and professional artists such as North herself. ${ }^{137}$ 
On another occasion, North described her visit with Barber to Hermann Franz Becker. This time Becker's stapelia garden was not the reason of Barber's visit. Becker showed the two women his insect collections, in particular a recently added beetle, which Barber took for a species of another group of insects. After a heated discussion, according to North, Barber left the room. Becker's wife then turned to North saying: 'As if the doctor did not know one when he saw it. Why, even at school he used to be called Beetle Becker.' Here, Becker assumed that Barber, who had not specialised in Coleoptera since childhood, possessed much less cultural capital than her husband and consequently could not be right. Barber's ambition and self-confidence flabbergasted North, who regarded Barber, twelve years her senior, as 'a most obstinate old lady'. ${ }^{138}$

Barber's encounters with both North and the Beckers offer a glimpse of how difficult it was for her to position herself within the transnational field of natural history, which was beholden to a patriarchal and class-conscious elite who regarded the metropole as eminently superior to the colony. Cultural and economic capital-education, access to collections and the financial means to afford first-class material-were held more important than life-long experience. North, who, in stark contrast to Barber, was unfamiliar with South African flora, displayed this attitude in disparaging Barber's works in comparison to her own.

North's behaviour is very similar to Joseph Hooker's attitudes towards and consorting with collectors in the colonial South. He did not allow his colleagues in New Zealand to name plants, as they had no access to the Royal Botanic Gardens Kew's herbarium, which he held for the largest and most important of its kind and therefore the only legitimate place for plant classification. At the same time, however, Hooker was dependent on their information and could not have published on New Zealand's flora without these local collectors. Indeed, he had only spent a brief period of time in New Zealand himself, during which he could not have hoped to collect enough data for such an undertaking. ${ }^{139}$

Similarly, North made use of Barber's knowledge while at the same time belittling her Cape counterpart. Old-fashioned as Barber's iconography might have been, North, who painted the specimens which she received in the comfort of her room, depended on Barber's experience and access to local flora and fauna. North even considered some of Barber's paintings to be worth copying, as the intervisual links between the images in Figs. $4.4,4.5$ and 4.6 indicate. ${ }^{140}$ 


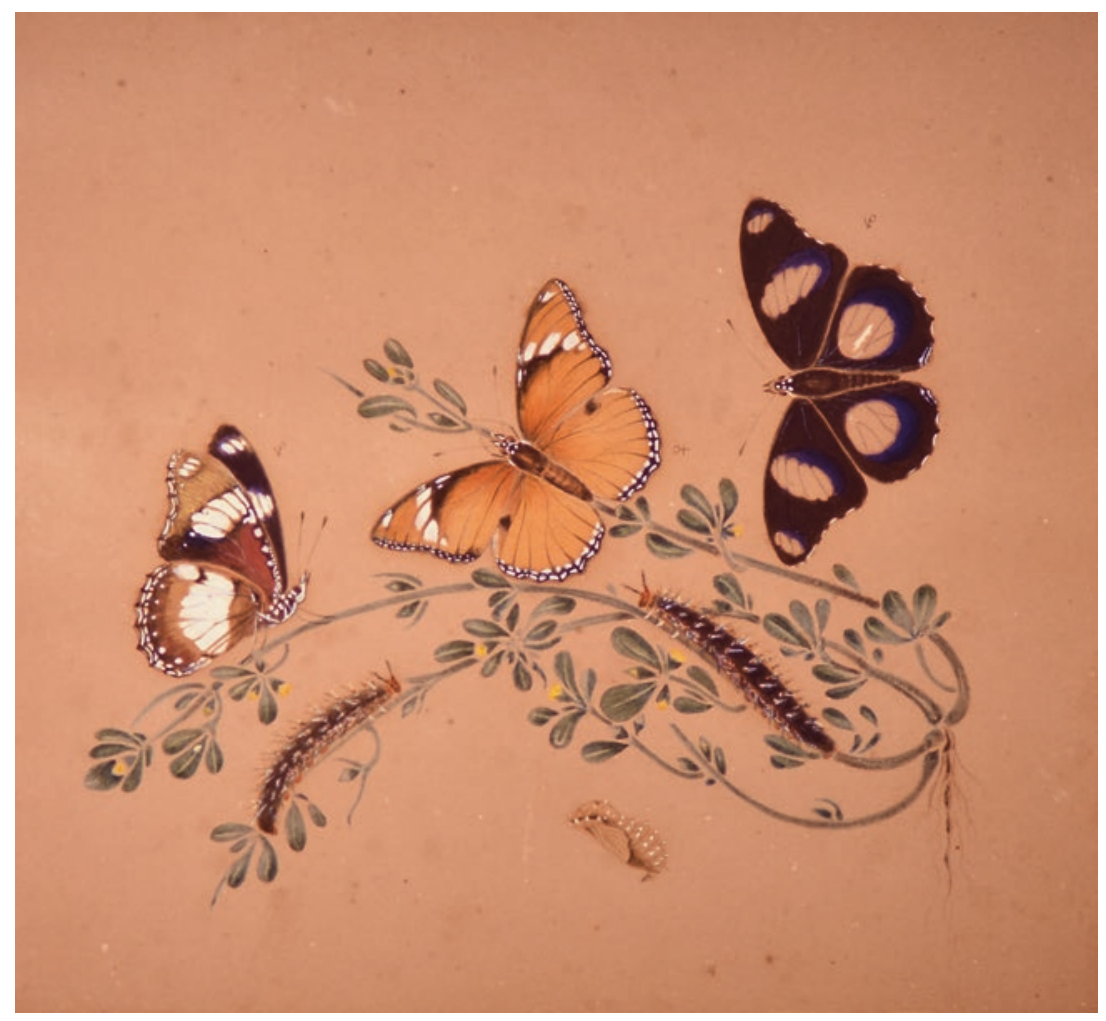

Fig. 4.4 Barber, Painting 31, Diadema misippus. It is unfinished as the missing colour in the male species shows, as if it was only a template for Marianne North. (Photographed by Tony Dold. (C) History Museum, Albany Museum Complex. All rights reserved)

While North's paintings have attracted considerable attention over the years, Barber's have not. Thousands of visitors see North's paintings every year in her gallery at the Royal Botanic Gardens Kew, which remains the only permanent solo exhibition by a woman artist in Great Britain and one of the largest solo exhibitions in the world. ${ }^{141}$ Viewers learn about North in popular books. ${ }^{142}$ Barber's illustrations, in stark contrast, have never been exhibited in a solo exhibition, and she was not a member of any British scientific society. Some of Barber's paintings have been exhibited in temporary exhibitions in South Africa: In 1978, seven of Barber's 


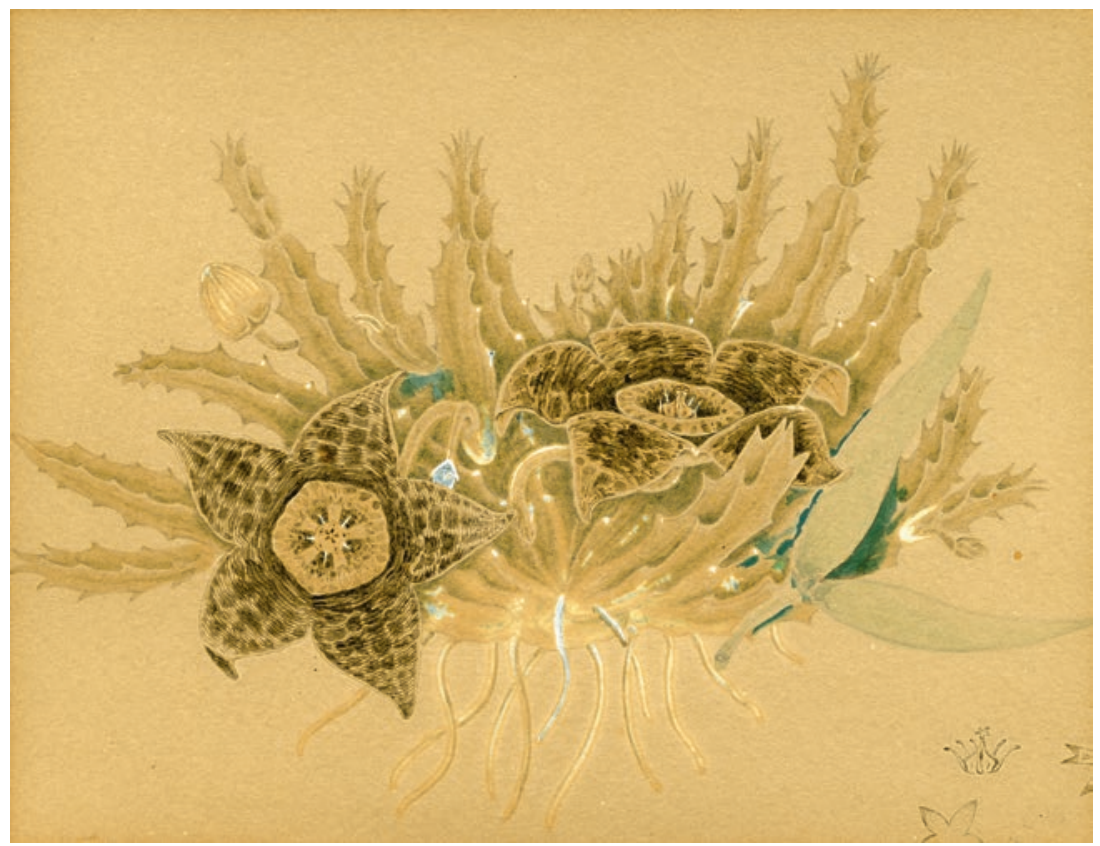

Fig. 4.5 Barber, Painting 56, Stapelia variegate L. var bufonia Nicholas Edward Brown. (Photographed by Tony Dold. (c) Selmar Schonland Herbarium)

Kimberley watercolours were offered on loan to the McGregor Museum in Kimberley and were on display there from 1979. ${ }^{143}$ Small special exhibitions were organised on National Woman's Day, 8 August 2003, at the Observatory Museum, Grahamstown, and in the exhibition 'Art as Science' at the History Museum, Albany Museum Complex, during the National Science Festival in Grahamstown, January to May 2011. Barber's watercolour of the butterfly Precis sesamus (Drawing No 29) is on permanent display in the Bowker Case in the Nineteenth Century Lifestyles Gallery, History Museum, Albany Museum Complex.

The connection between the two women's paintings - forged through their exchange of knowledge and personal competition between themhas likewise been forgotten. North who felt vastly superior may not have directly seen Barber as a competitor, and Barber may have primarily been concerned with her local competitors at the Cape. Yet, they competed with each other in their quest for recognition. 


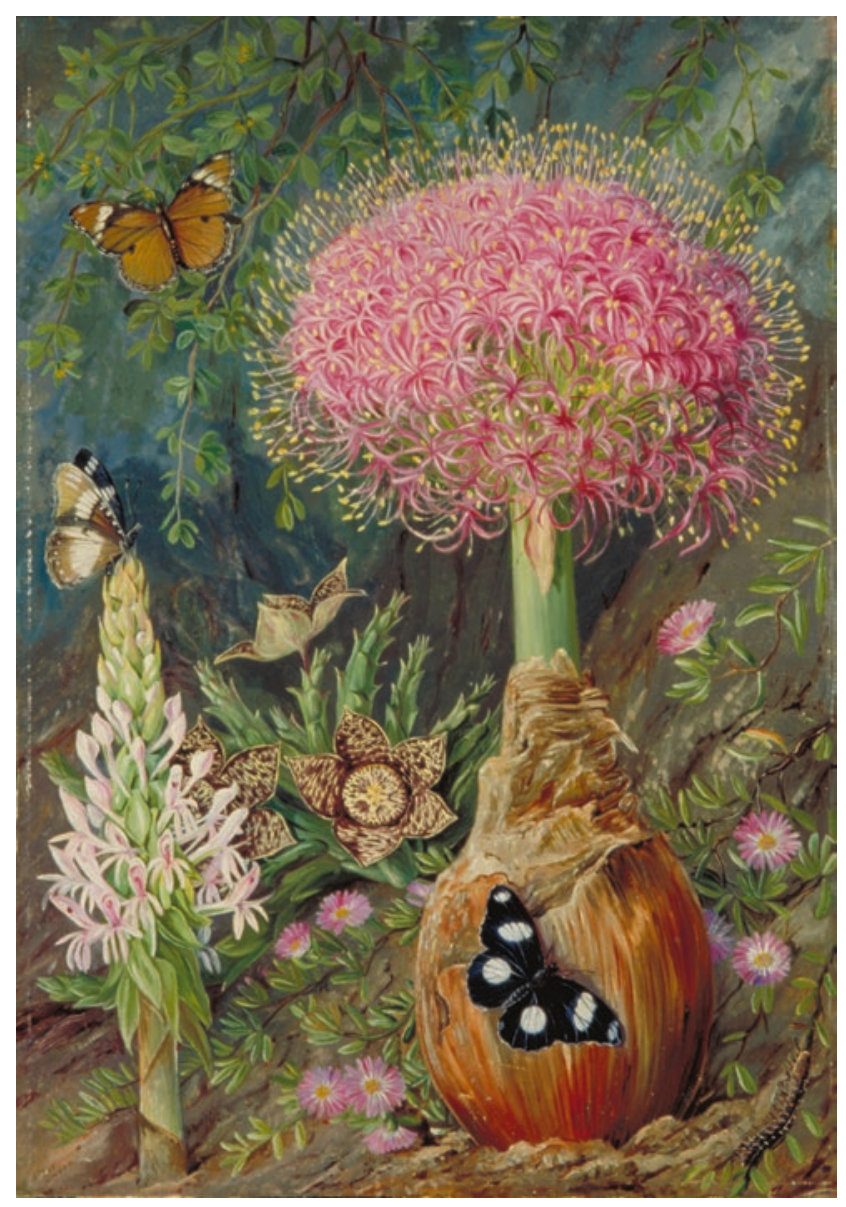

Fig. 4.6 North. Painting 395, Flowers of Grahamstown: Buphane toxicara, Zygophyllum, Stapelia bufonia, Orchid, Satyrium longicolle. (C) The Trustees of the Royal Botanic Gardens, Kew. All rights reserved)

The limited acceptance which women scientists met with, in turn, led to fierce battles among themselves for the scraps of scientific success as opposed to increased collaboration or solidarity among them. Portraying themselves as independent scientists meant in turn neglecting the contributions of co-operators further down the colonial social hierarchy than themselves. 
The status of 'lay scientist' was externally attributed to demean contestants; however, in certain instances, such individuals could suddenly become more valued for their knowledge and expertise. As Chap. 5 shows, this happened when they provided crucial missing information for a theory produced in the North. This corroborative evidence from the South was essential for it to be accepted as a universal theory. Proofs were required for the general public to overcome the 'epistemological rupture' when a new theory challenged familiar concepts. ${ }^{144}$

\section{Notes}

1. (MacOwan 1886, xxx).

2. KLAA, Director's Correspondence, Vol. 59, Letter 8, Dr. W.G. Atherstone to Sir William Hooker, 9 March 1849.

3. (Desmond 1987, 69, 131).

4. See for example: (Redgrave and Bradlow 1958); (Alexander 1990); (Bank 1995, "Chapter 6. Images of 'Savages' in Colonial Art," 276-308).

5. See (Cohen 2000, 188-191).

6. See for example: (Webb 1966, 35).

7. See: (Nelson 1992); (Parnell 2009).

8. See for example (Cohen 2011, 24).

9. KLAA, Director's Correspondence, Vol. 59, Letter 7, Dr. W. G. Atherstone to Sir William Hooker, 9 January 1849.

10. See for example: http://www.cam.ac.uk/research/news/darwinswomen, date accessed 23 December 2016.

11. (Harvey 1838, 1-2); Harvey, "Introduction", in (Hooker 1868, 9).

12. (Webb 1991, 306).

13. (Parnell 2009, 514).

14. RES, Trimen Correspondence, Box 19, Letter 206, Highlands, 6 May 1863.

15. See for example: KwaZulu-Natal Museum, Archive and Library, Pietermaritzburg.

16. Unlike Trimen and Harvey who are hardly known, much research has been conducted on Joseph Dalton Hooker, which is why I waive an introduction, assuming that it would be similarly superfluous as introducing Darwin. See for example (Endersby and Griggs 2011); (Endersby 2011); (Endersby 2010); (Endersby 2009); (Endersby 2008).

17. (Hooker 1866). For a reproduction of a hand-coloured plate, see: http://www.biodiversitylibrary.org/item/14368\#page/286/ mode/lup, date accessed 6 September 2016. 
18. RES, Trimen Correspondence, Box 18, Letter 109, Kimberley, 27 November 1878.

19. Joseph Dalton Hooker to William Wilson, 28 August 1844, KLAA, Director's Correspondence, Vol. 13, Letters 382-383. See (Secord 2002, $34)$.

20. (Huxley 1918, 1:189).

21. KLAA, Director's Correspondence, Vol. 189, Letter 114, Barber to Hooker, Highlands, 9 May 1867.

22. (Barber 1871).

23. She eventually asked Hooker in 1870 about what had become of her article. KLAA, Director's Correspondence, Vol. 189, Letter 123, Barber to Hooker, Highlands, 28 September 1870; Letter 124, Barber to Hooker, Highlands, 14 March 1871.

24. George Bentham to Charles Darwin, 25 Wilton Place S.W., 7 May 1869, Darwin Correspondence Project, Letter 6734.

25. He preferred fig 4 and suggested adding the outline in fig 3. SP 57, Linnean Society London; Darwin to Bentham, 10 May 1869, Letter 6740.

26. Darwin to Linnean Society, President and Council, 10 May 1869, Letter 6740, Darwin Correspondence Project.

27. Another interesting article in this regards is (Adams 1887); Also see: (Shteir 1996, 1997a, 1997b, 243).

28. (Barber 1871, 470), woodcut, $\pm 13 \times 16 \mathrm{~cm}$.

29. www.kew.org/heritage/people.fitch.html, date accessed 27 April 2013; "Alfred William Bennett", Proceedings of the Linnean Society of London: One Hundred and Fourteenth Session (1902), 26-27.

30. In his lecture "Verschenkt, unbeachtet, nie gesehen - Ausschuss im Labor" at the annual conference of eikones NCCR Iconic Criticism Einwegbilder, 24 October 2013, historian of science Christoph Hoffmann used the term 'Verstellung' which I translate here as 'misalignment'.

31. See for example (Endersby 2001).

32. (Creese and Creese 2010, 10).

33. See for example: (Syme 2016).

34. RES, Trimen Correspondence, Box 17, Letter 68/2, Highlands, 10 September 1869. In this letter, she writes that the paper in the Grabam's Town Journal was published 'a month or two ago'. This article was dated 24 May 1869 and read to the Albany Natural History Society, 24 June 1869, The Graham's Town Journal, CL: MIC 468, Reel No. 107, 15.1.1869-1.8.1870; 14353151.

35. RES, Trimen Correspondence, Box 17, Letter 69, Highlands, 20 November 1869. 
36. KLAA, Director's Correspondence, Vol. 189, Letter 123, Barber to J. D. Hooker, Highlands, 28 September 1870.

37. '2. A letter, dated Sierra Nevada, California, Oct. 28, 1870, from William Robinson, F. L. S., to Dr. Hooker, on the Californian Pitcherplant (Darlingtonia claifornica, Torrey). 3. "Carnivorous and Insectivorous Plants", by Mrs. Barber. Communicated by Dr. Hooker', Proceedings of the Linnean Society of London, (Session 1870-71), xxix.

38. (Cohen 2011, 61).

39. (Creese and Creese 2010, 10).

40. KLAA, JDH/3/6, from 1874. Thanks to Lorna Cahill for checking the Kew collection and Collin Harris for doing the same at the British Association for the Advancement of Science Collection at the Radcliffe Science Library, Bodleian Libraries, Oxford. All papers read to the Linnean Society, regardless of whether they were published or remained unpublished, should be archived, but Barber's is missing. Thanks to Elaine Charwat at the Linnean Society of London, Burlington House, London, for her double-checking.

41. (Gianquitto and Fisher 2014, 253-254).

42. See (Darwin $1875,97,129,452,453$ ).

43. (Hooker 1874, 366).

44. (Hooker 1874, 368).

45. See (Darwin 1875, 278). He writes: 'Mrs. Treat has given an excellent account in The American Naturalist, December 1873, p. 705, of Drosera longifolia (which is a synonym in part of Drosera anglica), of Drosera rotundifolia and filiformis.' See also (Darwin 1875, 311, 430) where he admits that he has 'largely quoted' her 'excellent observations'. Darwin also mentions flaws in her observations or in experiments which he made her do that were not successful (Darwin 1875, 281, 409, 430).

46. (Darwin 1875, 408-409); (Treat 1876).

47. See for example: (Treat 1873, 1875, 1875); all of these articles were reprinted in: (Treat 1885). For an interesting article on her contributions to Darwin's work, see: (Sanders 2009).

48. (Gianquitto and Fisher 2014, 254).

49. See (Albers and Meve 2004, 243).

50. (Bruyns 2005a, 1:2).

51. S. arnoti, S. gigantean, S. glabricaulis, S. kwebensis, S. leendertziae, S. longipedicellata, S. macowanii, S. olivacea, S. pearsonii, S. peglerae, S. pillansii, S. similis, S. surrecta and S. tsomoensis. See (Albers and Meve 2004, 242-255).

52. (Glen and Germishuizen 2010, 89-90); (Bruyns 2005a, 1:2).

53. See for example (Strohmeier 1998, 34); (Bruyns 2005b, 2:534); (White and Sloane 1937, 100). 
54. See for example 'Bushman engraving' on a rock in Schoolplaats, on the Vaal River near Kimberley, spotted by the South African geologist, botanist and director of the McGregor Museum in Kimberley Maria Wilman (1867-1957). She estimated it to be 600 years old, of 'the last period of the classical style' and published a rubbing of it. The upper position is lightly pecked, the base fairly deeply pitted (Wilman 1968, n.p.).

55. KLAA, Director's Correspondence, Vol. 189, Letter 130, Barber to J. D. Hooker, Kimberley, 4 June 1877.

56. RES, Trimen Correspondence, Box 18, Letter 124, Grahamstown, 26 July 1885.

57. (Glen and Germishuizen 2010,94-95); For more on Becker see: http:// www.s2a3.org.za/bio/Biograph_final.php?serial=197, date accessed 28 April 2016.

58. RES, Trimen Correspondence, Box 18, Letter 124, Grahamstown, 26 July 1885.

59. Hipolito Ruiz to Jorge Escobedo, 9 July 1768, (Bleichmar 2012, 90); (Barber 1903, 19).

60. However, they were published posthumously in: Barber, "Stapelias", $17-19$.

61. See, for example, KLAA, 107:141.01; 107:146 which documents Smith's working process, from the copying of a specific section of Barber's illustrations in watercolour to her final black-and-white line drawings.

62. (Hooker 1890, X, Part I:Stapelia desmentiana, Plate 1916).

63. See for example: (Desmond 1987, 36-37, 136-137, 157, 160, 162, 164, 184, 201); (Batcheller 1964); (N.A. 1916); (Turrill 1926); (Miss M. Smith 1922); (Miss Mathilda Smith 1921); (Matilda Smith 1927); (Royal Botanic Gardens, Kew 1927); http://www.kew.org/heritage/ people/smith_matilda.html, date accessed 20 December 2012.

64. Personal Correspondence Bruyns to Hammel, 13 December 2012; Personal Correspondence Linder to Hammel, 12 December 2012.

65. See for example: the diary of Sophie Beddoe, the governess employed by Bertram Egerton Bowker: Diary 1862-1864, CL: PR 7182.

66. For more on her family, see for example (Mitford-Barberton 1934); (Bowker 1964); (Mitford-Barberton and Mitford-Barberton 1952); (Mitford-Barberton 1970).

67. See Thomas Holden Bowker, Entomology Notebooks, 2, 9 January 1832, manuscript in leather, HM, SM 854.

68. KLAA, Director's Correspondence, Barber to Hooker, Vol. 189, Letter 116, Highlands, 24 July 1867.

69. (Cohen 1999, 124).

70. (North 1894, 2:274).

71. See for example: (Trimen 1870). 
72. RES, Trimen Correspondence, James Henry Bowker to Trimen, Box 19, Letters 10 to 91, Butterworth, Fort Bowker, Tsomo and Maseru, 18611869; Box 20, Maseru, Estcourt, Durban and others, Letters 271 to 350, 1869-1888; Box 21, Letters 1 to 39, Durban, 1889-1894.

73. See (Trimen 1901, 41); (Bethune-Baker 1916, 231).

74. RES, Trimen Correspondence, Box 17, Letters 29 to 80, 1863-1870, including ten drawings; Box 18, Letters 81 to 133, 1871-1888, including twelve hand-drawn coloured illustrations; Box 19, Letter 30.

75. See for example: RES, Trimen Correspondence, Box 17, Letter, 72, Highlands, 16 January 1870.

76. See (Neave 1933).

77. (Barber 1980, 37); (Ferry 2010).

78. 1833-36 Mrs. J. Curteis, 1835-47 Mrs. F. W. Hope, 1849-59 Mrs. Vines, 1854-80 Miss S. Thompson, 1878-1901 Miss E. A. Ormerod Hon. LL.D., 1880-96 Miss G. E. Ormerod (1896), 1880-82 Miss E. A. Smith, 1890-93 Mrs. E. Bazett, 1890-1904 Mrs. H. S. Chorley (formerly Miss M. Kimber), 1892-1928 Hon. Mrs. W. Carpenter, 18971906 Mrs. E. Brightwen, Miss E. F. Chawner, 1898 Miss M. E. Fountaine, see (Neave 1933, 162-181).

79. See "Mary Ball (1812-1898)" in (Creese and Creese 2004, 37-39).

80. See for example: (Davis 1997, 140-202); (Le-May Sheffield 2001, 139-194).

81. Barber to Trimen, RES, Trimen Correspondence, Box 17, Letter 42, Highlands, 1 May 1865.

82. (Harvey 1838); (Trimen 1862); (Layard 1867).

83. RES, Trimen Correspondence, Box 18, Letter 101, Barber to Trimen, Kimberley, 2 November 1877; Letter 107, Kimberley, 17 August 1878.

84. RES, Trimen Correspondence, Box 18, Letter 123, Barber to Trimen, Grahamstown, 24 April 1885.

85. See for example: RES, Trimen Correspondence, Box 17, Letter 39, Highlands, 6 September 1864.

86. Roland Trimen, "Introduction", [Hindhead, Haslemere, 1898], in (Barber 1898, vii-viii).

87. M. E. Barber to Mary Anne Mitford (née Bowker), 20 July 1847, HM, SM 5325 (4).

88. RES, Trimen Correspondence, Box 17, Letter 60, 21 June 1868; Letter 80/2, 13 November 1870; Box 18, Letter 108, Kimberley, 2 September 1878.

89. RES, Trimen Correspondence, Box 17, Letter 76 Highlands, 18 April 1870; Box 18, Letter 83, Highlands, 14 March 1871; (Cosser 1992, 199); RES, Trimen Correspondence, Box 17, Letter 64, Highlands, 29 February 1869; Letter 66, Highlands, 14 June 1869; Letter 75/1, 
Highlands, 10 April 1870; Box 18, Letter 81, Highlands, 11/16 January 1871 .

90. (McCracken 2007): 80 .

91. (Cosser 1992, 199). Watercolours, HM, for example SM 6627 (1), SM 6627 (5-12); Am 3176c (2); H 751 (2).

92. See Sophie Beddoe's Diary 1862-1864, CL: PR 7182.

93. See for example (Trimen 1887a, 1:xi, 135, 185, 1887b, 2:128, 137, 154, $161,216-217,1889,3: 66,97,173,249,255,329,396,411,415-$ 416). For more on her daughter and her niece, Mary Layard Bowker, whom she trained as her successors, see Chap. 7.

94. (Glen and Germishuizen 2010, 457); http://www.s2a3.org.za/bio/ Biograph_final.php?serial=3115, date accessed 22 October 2016; For an undated photograph of White see: History Museum, Albany Museum Complex, donated by relatives, no number.

95. (Tabler 1960).

96. See for example (Barber 1880, 218).

97. (Mitford-Barberton and White 1968, 33).

98. (Mitford-Barberton 1934, 81).

99. See for example: Barber "On the Peculiar Colours of Animals in Relation to Habits of Life"; "Locusts and Locust Birds"; "The Dark Races of the Diamond Fields"; "In the Claims"; "Night at Du Toit's Pan"; “The Commetje Veldt of Kaffraria".

100. See for example: Mrs. M. E. Barber, "The Aloe"; Mrs. Barber, "On the Fertilisation and Dissemination of Duvernoia adhatodoides"; Mrs. M. E. Barber, "On the Structure and Fertilisation of Liparis Bowkeri".

101. (Jacobs 2016, 95).

102. (Layard 1867, 122).

103. See (Carey 2011).

104. (Cohen 2011, 34).

105. (Layland 1869).

106. RES, Trimen Correspondence, Box 18, Letter 84, Highlands, 13 April 1871. The supposed publications of the article in other European languages could not be traced.

107. RES, Trimen Correspondence, Box 17, Letter 77, Highlands, 14 May 1870 .

108. RES, Trimen Correspondence, Box 18, Letter 84, Highlands, 13 April 1871 .

109. (Holub 1881, 2:85).

110. RES, Trimen Correspondence, Box 18, Letter 115, Kruis fontein, 9 April 1882.

111. RES, Trimen Correspondence, Box 18, Letter 116, Junction Drift, 12 September 1882.

112. RES, Trimen Correspondence, Box 18, Letter 118/1, Broxley [(northeast of Port Elizabeth)], 29 May 1883. 
113. (Holub 1882, 2).

114. (N.A. 1883, 2).

115. RES, Trimen Correspondence, Box 18, Letter 115, Kruisfontein, 9 April 1882 .

116. RES, Trimen Correspondence, Box 18, Letter 115, Kruisfontein, 9 April 1882.

117. She is not mentioned in historical overviews such as: (Gill 1955, 4-5); (Walters 2003, 83-86); (Hockey et al. 2005); (Siegfried 2016).

118. (Bank 2006, 52); (Bennun 2004, 141, 278).

119. For further information see: http://www.s2a3.org.za/bio/Biograph_ final.php?serial=1182, date accessed 2 October 2016.

120. See Cornelius Plug, "Glanville, Miss Mary Elizabeth", http://www.s2a3. org.za/bio/Biograph_final.php?serial=1067, date accessed 29 September 2016.

121. N. Fowler, A History of the Albany Museum, 1855-1958. Manuscript, 1968, HM, No archival number, 54; The Economist, 4th June 1888, quoted in: Ibid., 57.

122. For more on Treat, see for example: (Gianquitto 2007, 136-176).

123. "The only women directors" [Ms M. Glanville 1882 to 1888 , and Dr. Lita Webley, 1999 to 2008], National Women's Day at the Albany Museum, 9 August 2009, leaflet, p. 1; Eleanor A. Ormerod, "Injurious farm and fruit insects in South Africa" quoted in: Fowler, A History of the Albany Museum, 58 .

124. "The Grahamstown Natural History Society", The Grabam's town Journal, Thursday, 25 February 1886.

125. "The Graham's town Natural History Society", The Graham's town Journal, Thursday, 25 February 1886.

126. See (Merchant 2010, 3-30); (Birdsall 2002).

127. See "The Graham's town Natural History Society", The Graham's town Journal, 19 July 1886.

128. This history of the development of natural history societies in Grahamstown is based on archival research in the History Museum, Albany Museum Complex, conversations with curator (emeritus) and genealogist Fleur Way-Jones and dates provided on different naturalists on the Southern Africa Association for the Advancement of Science's database $S_{2} A_{3}$ Biographical Database of Southern African Science, which was launched for the association's centenary in 2002. http://www.s2a3. org.za/bio/Main.php, date accessed 26 October 2016.

129. See for example: Royal Gardens, Kew, Official Guide to the North Gallery, sixth edition, revised and augmented, (London: His Majesty's Stationery Office, 1914).

130. In 1884-1885, she also painted the flora of the Seychelles and Chile. 
131. (McCracken 2007, 81).

132. (North 1894, 2:247).

133. C. J. Skead, "From Oldenland to Schonland - Two Centuries of Pioneer Plant Hunting in Today's Albany 'Hot-Spot'" (Private Publication, 2002), 249; also echoed in private conversation with Tony Dold and botanists at Kew.

134. RES, Trimen Correspondence, Box 17, Letter 53, Highlands, 1 November 1866. In at least one instance, Barber also reported having received paint from Trimen. RES, Trimen Correspondence, Box 17, Letter 62, Highlands, 2 November 1868.

135. See herbarium sheets at TCD.

136. (North $1894,2: 275$ ).

137. (North 1894, 2:279).

138. (North 1894, 2:251).

139. (Endersby 2001).

140. (North 1894, 2:247).

141. Peter Emery, "The Marianne North Gallery at Kew Gardens", http:// www.eynshamartsgroup.org.uk/The $\% 20$ Marianne $\% 20$ North $\% 20$ Gallery\%20at\%20Kew\%20Gardens.pdf, date accessed 23 October 2016, slide 51 .

142. See for example: (Payne 2011); (Brenan and Moon 1986).

143. The closing of the exhibition is not known, see Director's Correspondence, Folder on Barber, HM, Grahamstown.

144. See (Bachelard 1938).

\section{REFERENCES}

Adams, J.F.A. 1887. Is Botany a Suitable Study for Young Men? Scientific American 23: 9318-9318. https://doi.org/10.1038/scientificamerican 03051887-9318bsupp.

Albers, Focke, and Ulrich Meve. 2004. Illustrated Handbook of Succulent Plants: Asclepiadaceae. Berlin/Heidelberg: Springer Verlag.

Alexander, Lucy. 1990. Frederick I'Ons Retrospective Exhibition. Port Elizabeth: King George VI Art Gallery.

Bachelard, Gaston. 1938. La formation de l'esprit scientifique. Paris: Libraire Philosophique J.Vrin.

Bank, Andrew. 1995. Liberals and Their Enemies: Racial Ideology at the Cape of Good Hope, 1820 to 1850. Cambridge: Cambridge University Press.

- 2006. Bushmen in a Victorian World: The Remarkable Story of the BleekLloyd Collection of Bushman Folklore. Cape Town: Double Storey Press.

Barber, M.E. 1871. On the Fertilization and Dissemination of Duvernoia adhatodoides. Journal of the Linnean Society of London, Botany 11: 469-472. https:// doi.org/10.1111/j.1095-8339.1871.tb00156.x. 
1880. Locusts and Locust Birds. Transactions of the South African Philosophical Society 1: 193-218.

- 1898. The Erythrina Tree and Other Verses. London: Printed for Private Circulation.

- 1903. Stapelias. Kew Bulletin: 17-19.

Barber, Lynn. 1980. The Heyday of Natural History 1820-1870. London: Doubleday \& Company.

Batcheller, Frances. 1964. Mathilda Smith. General Saint Paulina News, April.

Bennun, Neil. 2004. The Broken String: The Last Words of an Extinct People. London: Viking.

Bethune-Baker, George T. 1916. Obituary, "Roland Trimen, F.R.S". The Entomologists' Record and Journal of Variation XXVIII: 231-236.

Birdsall, Amelia. 2002. A Woman's Nature: Attitudes and Identities of the Bird Hat Debate at the Turn of the 20th Century. Unpublished Senior Thesis, Haverford College.

Bleichmar, Daniela. 2012. Visible Empire: Botanical Expeditions and Visual Culture in the Hispanic World. Chicago: The University of Chicago Press.

Bowker, John Mitford. 1964. Speeches, Letters and Selections from Important Papers. Grahamstown 1864; Reprint Cape Town: Struik Reprint.

Brenan, J.P.M., and Brenda E. Moon, eds. 1986. A Vision of Eden: The Life and Work of Marianne North. Kew: Royal Botanic Gardens.

Bruyns, Peter V. 2005a. Stapeliads of Southern Africa and Madagascar. Vol. 1. 2 vols. Hatfield: Umdaus Press.

- 2005b. Stapeliads of Southern Africa and Madagascar. Vol. 2. 2 vols. Hatfield: Umdaus Press.

Carey, Hilary M. 2011. "The Secret of England's Greatness": Medievalism, Ornithology, and Anglican Imperialism in the Aboriginal Gospel Book of Sir George Grey. Journal of Victorian Culture 16: 323-346.

Cohen, Alan. 1999. Mary Elizabeth Barber, the Bowkers and South African Prehistory. The South African Archaeological Bulletin 54: 120-127.

- 2000. Mary Elizabeth Barber: South Africa's First Lady Natural Historian. Archives of Natural History 27: 187-208.

- 2011. In a Quiet Way: The Life of Mary Elizabeth Barber, South Africa's First Lady Natural Historian 1818-1899. Unpublished Manuscript.

Cosser, Marijke. 1992. Images of a Changing frontier: Worldview in Eastern Cape Art from Bushman Rockart to 1875. Rhodes University.

Creese, Mary R.S., and Thomas M. Creese. 2004. Ladies in the Laboratory II: West European Women in Science, 1800-1900, A Survey of Their Contributions to Research. Lanham/Oxford: The Scarecrow Press Inc.

-2010. South African, Australian, New Zealand, and Canadian Women in Science, Nineteenth and Early Twentieth Centuries, A Survey of Their Contributions, Ladies in the Laboratory 3. Lanham/Toronto/Plymouth: The Scarecrow Press Inc. 
Darwin, Charles R. 1875. Insectivorous Plants. London: John Murray.

Davis, Natalie Zemon. 1997. Women on the Margins: Three Seventeenth-Century Lives. Cambridge, MA: Harvard University Press.

Desmond, Ray. 1987. A Celebration of Flowers: Two Hundred Years of Curtis's Botanical Magazine. London: Bentham-Moxon Trust Royal Botanic Gardens, Kew.

Endersby, Jim. 2001. 'From Having No Herbarium': Local Knowledge vs. Metropolitan Expertise: John Hooker's Australasian Correspondence with William Colenso and Ronald Gunn. Pacific Science 55: 343-358.

- 2008. Joseph Hooker: A Philosophical Botanist. Journal of Biosciences 32: 163-169.

- 2009. Lumpers and Splitters: Darwin, Hooker, and the Search for Order. Science 326: 1496-1499.

- 2010. Imperial Nature: Joseph Hooker and the Practices of Victorian Science. Chicago/London: The University of Chicago Press.

- 2011. A Life More Ordinary: The Dull Life but Interesting Times of Joseph Dalton Hooker. Journal of the History of Biology 44: 611-631.

Endersby, Jim, and Pat Griggs. 2011. Joseph Dalton Hooker: Botanical Trailblazer. Kew: Kew Publishing.

Ferry, Georgina. 2010. The Exception and the Rule: Women and the Royal Society 1945-2010. Notes and Records of the Royal Society 64: 1-10.

Gianquitto, Tina. 2007. "Good Observers of Nature". American Women and the Scientific Study of the Natural World, 1820-1885. Athens/London: University Press.

Gianquitto, Tina, and Lydia Fisher. 2014. America's Darwin: Darwinian Theory and U.S. Literary Culture. Athens/London: The University of Georgia Press.

Gill, E.L. 1955. Fifty Years of South African Ornithology. The Ostrich, 4-5.

Glen, Hugh Francis, and Gerrit Germishuizen. 2010. Botanical Exploration of Southern Africa. 2nd ed. Strelitzia 26. Pretoria: South African National Biodiversity Institute.

Harvey, William Henry. 1838. The Genera of South African Plants: Arranged According to the Natural System. Cape Town: A. S. Robertson.

Hockey, P.A.R., W.R.J. Dean, and P.G. Ryan. 2005. Roberts - Birds of Southern Africa. 7th ed. Cape Town: Trustees of the John Voelcker Bird Book Fund.

Holub, Emil. 1881. Seven Years in South Africa, Travels, Researches, and Hunting Adventures, Between the Diamond-Fields and the Zambesi, 1872-79. Vol. 2. London: Sampson Low, Marston, Searle \& Rivington.

— 1882. Dr. Holubs Vortrag über die Vogelwelt Südafrikas. Mittheilungen Des Ornithologischen Vereins in Wien: Blätter Für Vogelkunde, Vogel-Schutz Und -Pflege: $1-7$.

Hooker, Joseph Dalton. 1866. Brachystelma barberiae, Mrs. Barber's Brachystelma. Curtis's Botanical Magazine 92: tab. 5607. 
1868. The Genera of South African Plants: Arranged According to the Natural System. 2nd ed. Cape Town: J. C. Juta.

- 1874. The Carnivorous Habits of Plants. Nature 10: 366-372.

- 1890. Icones Plantarum; or, Figures, with Descriptive Characters and Remarks, of New and Rare Plants, Selected from the Kew Herbarium. Vol. X, Part I. 3. London: Williams \& Norgate.

Huxley, Leonard. 1918. Life and Letters of Sir Joseph Dalton Hooker. Vol. 1. London: John Murray.

Jacobs, Nancy J. 2016. Birders of Africa: History of a Network. New Haven/ London: Yale University Press.

Layard, Edgar Leopold. 1867. The Birds of South Africa: A Descriptive Catalogue of All the Known Species Occurring South of the 28th parallel of South Latitude. Cape Town/London: Juta/Longman, Green \& Co.

Layland, Mr. 1869. The Cave Cannibals of South Africa. Journal of the Ethnological Society of London 1: 76-80.

Le-May Sheffield, Suzanne. 2001. Revealing New Worlds. Three Victorian Women Naturalists. London/New York: Routledge.

MacOwan, Peter. 1886. Personalia of Botanical Collectors at the Cape. Transactions of the South African Philosophical Society IV: xxx-liii.

Matilda, Smith. 1927. Journal of the Kew Guild: 527-528.

McCracken, Donald P. 2007. Plant Hunting and the Provenance of South African Plants in British Botanical Magazines, 1787-1910. In Sights and Insights: Interactive Images of Europe and the Wider World, ed. Mary N. Harris, 75-89. Pisa: Pisa University Press.

Merchant, Carolyn. 2010. George Bird Grinnell's Audubon Society: Bridging the Gender Divide in Conservation. Environmental History 15: 3-30.

Miss M. Smith. 1922. Journal of the Kew Guild: 83-86.

Miss Matilda Smith. 1921. Kew Bulletin 8: 317-318.

Mitford-Barberton, Ivan. 1934. The Barbers of the Peak. A History of the Barber, Atherstone, and Bowker Families. Oxford: Oxford University Press.

- 1970. Comdt. Holden Bowker. An 1820 Settler Book Including Unpublished Records of the Frontier Wars. Cape Town/Pretoria: Human and Rousseau.

Mitford-Barberton, Ivan, and Raymond Berners Mitford-Barberton. 1952. The Bowkers of Tharfield. Oxford: Oxford University Press.

Mitford-Barberton, Ivan, and Violet White. 1968. Some Frontier Families. Biographical Sketches of 100 Eastern Province Families Before 1840. Cape Town/ Pretoria: Human and Rousseau.

N.A. 1883. Verzeichnis der Mitglieder des Ornithologischen Vereins in Wien. Beilage zu Nr. 2 der Mittheilungen des Ornithologischen Vereines in Wien.

- 1916. Miss Matilda Smith. Journal of the Kew Guild: 265-266.

Neave, Sheffield Airey. 1933. The History of the Entomological Society of London, 1833-1933. London: Entomological Society of London. 
Nelson, E. Charles. 1992. William Henry Harvey as Colonial Treasurer at the Cape of Good Hope: A Case of Depression and Bowdlerised History. Archives of Natural History 19: 171-180.

North, Marianne. 1894. Recollections of a Happy Life: Being the Autobiography of Marianne North, edited by her sister Mrs. John Addington Symonds, ed. John Addington Symonds. Vol. 2. 3 vols. New York/London: Macmillan.

Parnell, John. 2009. W. H. Harvey. In Dictionary of Irish Biography: From the Earliest Times to the Year 2002, ed. James McGuire and James Quinn, vol. 4, 513-514. Cambridge: Cambridge University Press.

Payne, Michelle. 2011. Marianne North: A Very Intrepid Painter. Kew: Kew Publishing.

Redgrave, John Joseph, and Edna Bradlow. 1958. Frederick I'Ons, Artist. Cape Town: Maskew Miller.

Royal Botanic Gardens, Kew. 1927. Miss Matilda Smith. Bulletin of Miscellaneous Information: 135-139.

Sanders, Dawn. 2009. Behind the Curtain: Treat and Austin's Contributions to Darwin's Work on Insectivorous Plants and Subsequent Botanical Studies. Jabrbuch für Europäische Wissenschaftskultur 5: 215-228.

Secord, Anne. 2002. Botany on a Plate: Pleasure and the Power of Pictures in Promoting Early Nineteenth-Century Scientific Knowledge. Isis 93: 28-57.

Shteir, Ann B. 1996. Cultivating Women, Cultivating Science: Flora's Daughters and Botany in England, 1760 to 1860. Baltimore: The Johns Hopkins University Press.

- 1997a. Gender and 'Modern' Botany in Victorian England. Osiris 12: 29-38.

- 1997b. Elegant Recreations? Science Writing for Women. In Victorian Science in Context, ed. Bernard Lightman, 236-255. Chicago: The University of Chicago Press.

Siegfried, Roy. 2016. Levaillant's Legacy: A History of South African Ornithology. Noordhoek: Print Matters.

Strohmeier, Renate. 1998. Lexikon der Naturwissenschaftlerinnen und naturkundigen Franen Europas. Frankfurt a.M: Harri Deutsch Verlag.

Syme, Alison. 2016. Über Geschichten von pflanzlichen Vampiren - oder moderne Verbrauchernachrichten. In Floriographie: Die Sprachen der Blumen, ed. Isabel Kranz, Alexander Schwan, and Eike Wittrock, 315-336. Paderborn: Wilhelm Fink.

Tabler, Edward C., ed. 1960. Zambesia and Matabeleland in the Seventies: The Narrative of Frederick Hugh Barber 1875 and 1877-1878 and The Journal of Richard Frewin 1877-1878. London: Chatto \& Windus.

Treat, Mary. 1873. Observations on the Sundew. The American Naturalist 7: 705-708.

. 1875. Plants that Eat Animals. American Naturalist 9: 658-662. 
1876. Is the Valve of Utricularia Sensitive? Harpers New Monthly Magazine 52: $382-387$.

- 1885. Home Studies in Nature. New York/Cincinnati/Chicago: American Book Company.

Trimen, Roland. 1862. Rhopalocera Africae Australis: A Catalogue of South African Butterflies: Comprising Descriptions of All the Known Species, with Notices of Their Larvae, Pupae, Localities, Habits, Seasons of Appearance, and Geographical Distribution. London: Trübner.

- 1870. Notes on Butterflies Collected by J. H. Bowker, Esq., in Basutoland, South Africa; with Descriptions of some new Species. Transactions of the Royal Entomological Society of London 18: 341-390.

- 1887a. South-African Butterflies: A Monograph of the Extra-Tropical Species, Nymphalidae. Vol. 1. London: Trübner \& Co.

- 1887b. South-African Butterflies: A Monograph of the Extra-Tropical Species, Erycinidae and Lycaenidae. Vol. 2. London: Trübner \& Co.

- 1889. South-African Butterflies: A Monograph of the Extra-Tropical Species, Papilionidae and Hesperidae. Vol. 3. London: Trübner \& Co.

- 1901. Obituary Notices, James Henry Bowker. In Proceedings of the Linnean Society of London, 113th session, November 1900 to June 1901, 40-41. Turrill, W.B. 1926. Proceedings of the Linnean Society: 99-102.

Walters, Michael. 2003. A Concise History of Ornithology: The Lives and Works of Its Founding Figures. London: Christopher Helm.

Webb, David A. 1966. William Henry Harvey 1811-1866 and the Tradition of Systematic Botany. Hermathena 103: 32-45.

. 1991. The Herbarium of Trinity College: Its History and Contents. Botanical Journal of the Linnean Society 106: 295-327.

White, Alain Campbell, and Boyd L. Sloane. 1937. The Stapelieae. Pasadena: Abbey San Encino Press.

Wilman, Maria. 1968. The Rock-Engravings of Griqualand West and Bechuanaland, South Africa. Cape Town: Balkema. 
Open Access This chapter is licensed under the terms of the Creative Commons Attribution 4.0 International License (http://creativecommons.org/licenses/ by $/ 4.0 /$ ), which permits use, sharing, adaptation, distribution and reproduction in any medium or format, as long as you give appropriate credit to the original author(s) and the source, provide a link to the Creative Commons licence and indicate if changes were made.

The images or other third party material in this chapter are included in the chapter's Creative Commons licence, unless indicated otherwise in a credit line to the material. If material is not included in the chapter's Creative Commons licence and your intended use is not permitted by statutory regulation or exceeds the permitted use, you will need to obtain permission directly from the copyright holder.

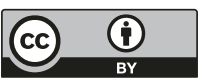

